\title{
PLACE OF ELECTROPHORETIC DEPOSITION AMONG THIN-FILM METHODS ADAPTED TO THE SOLID OXIDE FUEL CELL TECHNOLOGY: A SHORT REVIEW
}

\author{
ELENA YU. PIKALOVA ${ }^{1,2}$ \& ELENA G. KALININA ${ }^{1,3}$ \\ ${ }^{1}$ Ural Federal University, Russia. \\ ${ }^{2}$ Institute of High Temperature Electrochemistry UB RAS, Russia. \\ ${ }^{3}$ Institute of Electrophysics UB RAS, Russia.
}

\begin{abstract}
Thin film technologies have attracted ever-growing interest in different industrial areas. Concerning solid oxide fuel cells (SOFCs), especially devices operating in the intermediate temperature range, such technologies are applied particularly for the deposition of dense, gas-tight electrolyte films with a thickness of several $\mu \mathrm{m}$ to decrease ohmic resistance and enhance the cell performance. The main requirements for the technology selected are its low cost, simplicity of the equipment used, short deposition time and flexibility regarding the cell shape. First, we overview thin-film technologies adapted to the deposition of SOFC functional layers, discussing their strengths and weaknesses, with special attention given to electrophoretic deposition (EPD) as being the most simple and cost-effective colloidal method to fabricate different electrolyte films. Then we present the contribution of our scientific group in the development of the EPD method. The preparation of stable suspensions for the EDP is one of the key requirements for its successful implementation and reproducibility; this was considered in detail and the effect of self-stabilization in suspensions based on nanopowders (7-15 $\mathrm{nm}$ ), obtained by the method of laser evaporation with consequent condensation, was discussed. Such suspensions, exhibiting high positive $\zeta$-potential values ( $30-50 \mathrm{mV}$ ), were shown to be suitable for EPD without the addition of dispersants or iodine. The requirements for the electrode substrates were formulated and a model of particle aggregation near the porous substrate surface was proposed. Deposition parameters were established for different electrolyte films - commonly used yttria-stabilized zirconia, single and multiply doped $\mathrm{CeO}_{2}$ and proton-conducting doped $\mathrm{BaCeO}_{3}$ electrolytes. As was shown, the deposition on the highly conducting cathode substrates is simpler to implement than the EPD on non-conducting anode substrates and, in addition, it produces high quality films which render high OCV values and superior SOFC performance.

Keywords: cathode substrate, electrolyte film, electrophoretic deposition, SOFC, thin-film technology.
\end{abstract}

\section{INTRODUCTION}

Solid oxide fuel cells (SOFCs) are considered to be promising power sources for decentralized electricity production, individually or in combination with renewable energy sources [1]-[3]. Both the academic community and the manufacturers have maintained a high level of interest in investigations in this area to finally overcome the problem with their commercialization and reduction in price per $\mathrm{kW}$ of power produced. Decreasing the SOFC operational temperature is dictated by the necessity of significantly reducing the rate of degradation processes and extend the choice of cheaper electrode and interconnecting materials used. Along with the development of new materials with advanced functional characteristics in an intermediate temperature range $\left(600-750^{\circ} \mathrm{C}\right)[4]-[8]$, peculiar methods are applied to fabricate thin SOFC layers. Since the electrolyte thickness in second-generation SOFCs [9] decreases to a 5-10 $\mu \mathrm{m}$ range, it can no longer be the cell supporting element, so a new design of SOFC with supporting electrodes (anode or cathode) or metal-supported cells has been developed [10]-[12]. The thin-film electrolyte allows high performance of the cells to be preserved at decreased temperatures including those with traditional yttria-stabilized zirconia (YSZ) electrolytes [13]-[15]. Thin-film technology is also advantageous in deposition of 
barrier layers on the electrode-electrolyte interface, functionally graded electrodes and Cr-protective oxide layers for interconnectors [16]-[19]. In general, the methods for producing thin films are divided into physical, chemical and ceramic methods (Fig. 1). Plasma-assisted methods, wet chemical methods, colloidal and electrochemical methods [20],[21] can also be included. The list of methods for thin film production being applied to SOFC technology has been constantly growing. Modern integrated technologies are now directed towards entire cell production, especially when producing micro-SOFCs. However, it should be noted, that the majority of thin-film methods require complicated equipment. Electrophoretic deposition (EPD) is one of the colloidal processes in which a ceramic film is formed on a substrate from an electrostatically stabilized colloidal suspension in an electric field [22, 23]. The EPD method was chosen by our scientific group for the fabrication of thin electrolyte films for several reasons: it does not require expensive equipment; it is less time-consuming in comparison to the majority of chemical and physical methods (about $1 \mu \mathrm{m}$ per minute) and is easily adaptable to changes in the electrolyte compositions and substrate shapes. To the best of our knowledge, there have only been a few reviews devoted to the application of thin-film technology for SOFCs with a little or no attention given to the EPD itself [9], [13], [14], [18], [20], [21] or to the EDP (fundamentals and application in different areas), where the application of the EPD in the SOFC technology was considered only in brief [22], [23], [24].

Growing interest in the application of the EPD technology for SOFCs in Russia has compelled us to present a review of recent improvements in the EPD technology, including our own achievements, and also attempt to determine this method's place among the others technologies adapted for SOFC formation in order to evaluate its prospects.

In Section 2, we give a short review of recent work on the application of different thin-film technologies in SOFC manufacture with a discussion of their advantages and disadvantages.

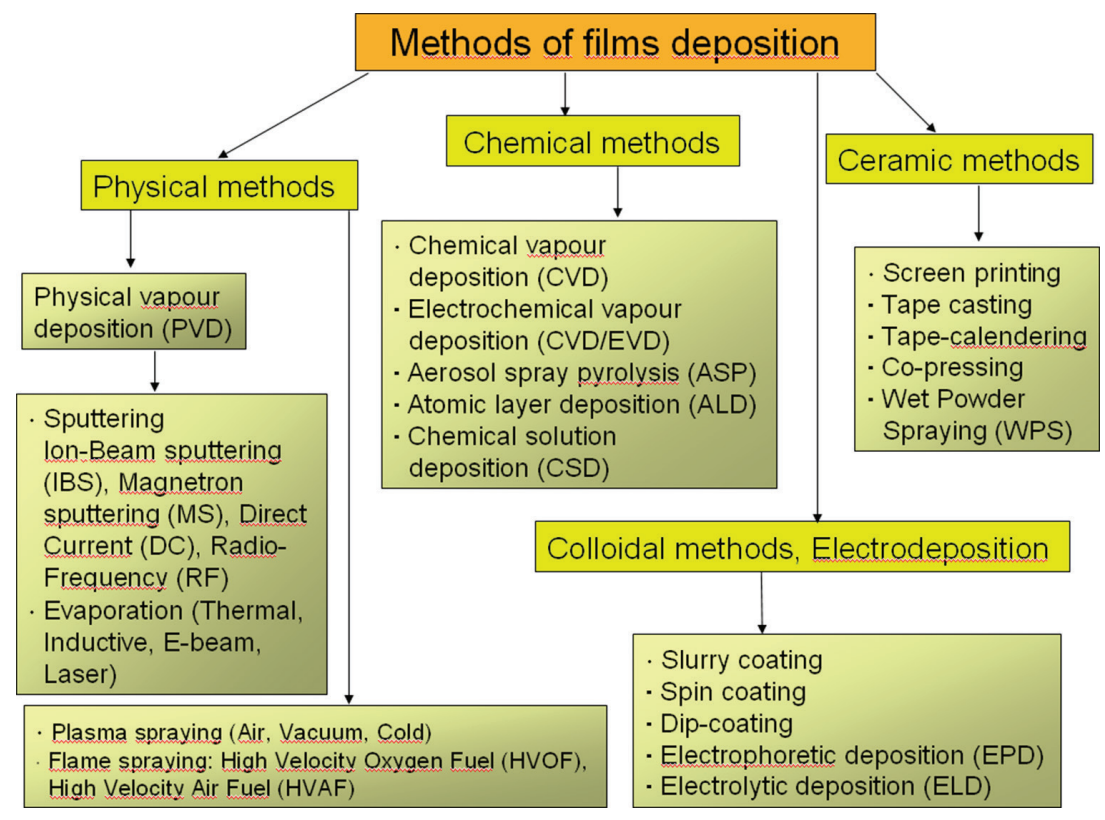

Figure 1: Thin-film methods adapted to the deposition of the SOFC functional layers. 
Also chemical solution and colloidal methods are reviewed with special attention given to EPD to show the place of the EPD among the other methods and its practical perspectives. The subsequent chapters are dedicated to our recent achievements in EPD. In discussion, we give examples from the studies of different groups as well for the sake of comparison.

As far as the successful implementation of the EPD process and its reproducibility is largely determined by preparation of stable suspensions, in Section 3, we present our the main findings, that is, self-stabilized suspensions for EPD based on nano-sized powders, obtained by the method of laser evaporation with subsequent condensation.

In Section 4, we discuss important issues relevant to the successful production of best quality films such as deposition parameters and requirements for the electrode substrates and then present examples of deposition of different solid-state films from the stabilized suspensions ( $\mathrm{YSZ}, \mathrm{CeO}_{2}, \mathrm{BaCeO}_{3}$ ). Additionally, we discuss the SOFC performance for the cells obtained using the EPD method and an important parameter, the OCV value characterizing the electrolyte film quality, including the results obtained by our group on the cathode supported cell.

\section{METHODS ADAPTED FOR THE THIN FILM DEPOSITION IN THE SOFC TECHNOLOGY}

\subsection{Ceramic methods}

Tape casting, screen printing and tape calendaring are the most commonly used ceramic techniques for cost-effective thin SOFC layer formation [9],[21]. Screen-printing is a method of applying a film by extruding a viscous paste consisting of a mixture of ceramic powder, an organic binder and a plasticizer through a grid. This method is widely applied for the electrode layers' formation and can be used for formation of thin electrolyte films on porous substrates [20],[21]. High shrinkage due to burning of organic components and high sintering temperatures, however, often results in low-quality films obtained by screen printing. Preparation of a printing paste using a mixture of highly reactive sol-gel precursors with micro-sized oxide powders offers the opportunity to obtain crack-free, gas-tight electrolyte layers with a thickness of a few microns [25].

Tape casting is a commercial technology traditionally used for the production of functional ceramics with a thickness of 25-1000 $\mu \mathrm{m}$ and has also been successfully used to form planar SOFC elements with a supporting anode. The process includes the distribution of the slip, consisting of a ceramic component with the addition of a modifier, an organic ligament, dispersant (fish oil) and a solvent (alcohol or toluene), over a flat surface where it remains until the solvents evaporate. Usually, a green anode film has thickness of 1-2 mm and electrolyte film —of 40-100 $\mu \mathrm{m}$, then they are laminated, co-rolled or calendared, and elements of the required size are cut out and sintered at temperatures of $1300-1400^{\circ} \mathrm{C}$ in special furnaces to avoid deformation of the elements. As a rule, the final thickness of electrolyte layers reaches 15-100 $\mu \mathrm{m}$ [26]. In this technology, the incompatibility of the expansion of laminated materials during heat treatment becomes critical, which can lead to deformation, cracking and delaminating of the sandwich [27].

Tape-calendaring is gradual rolling of ceramic films in order to obtain an electrolyte film with a thickness of 10-30 $\mu \mathrm{m}$ on a carrier anode [28]. Thin electrolyte and anode films are rolled from plastic mixture prepared from ceramic powders with an organic binder (based, for example, on natural rubber), which are then co-rolled together to produce a two-layer 
anode-electrolyte film. Then this film is laminated with a thick anode film and subjected to co-rolling again. The process is repeated to achieve the desired thickness of the electrolyte film. After burning the organic binder, the finished product is sintered at a temperature that will both derive a porous-free electrolyte layer and, at the same time, retain the porous anode structure. The process is simple and allows ceramic elements with a size of up to $500 \mathrm{~cm}^{2}$ to be fabricated [29].

Co-pressing and co-firing process is a simple and inexpensive approach to fabricate dense electrolyte thin-film of approximately $10 \mu \mathrm{m}$ on a porous anode. Initially, it was used only for the formation of small-size cells but today the technology is in the process of scaling [30], [31]. Wet powder spraying has been considered recently as a promising processing route for the straightforward and cheap fabrication of dense thin film electrolytes. This non-contact technique is applicable both to planar surfaces or tubes with high deposition rates and, with appropriate spraying parameters being established, allows crack-free, highly dense electrolyte films with a thickness of approximately 5-10 $\mu \mathrm{m}$ to be obtained [32].

\subsection{Physical methods}

Methods of the physical vapour deposition (PVD) series are based on the gas phase formation via evaporation (thermal, inductive, e-beam, laser) or sputtering (ion beam, magnetron, $\mathrm{DC}, \mathrm{RF}$ ) followed by transportation of the material in its atomic state from the source target and its condensation on the substrate with the film formation. These methods are usually carried out in a vacuum or inert gases and require complicated equipment. The rate of deposition is quite high - about 1000 atomic layers/s; however, thickness control is difficult. Among the disadvantages of the evaporation methods one can mention also contamination of the film with the container material (thermal evaporation) and the difference in the resulting film stoichiometry from that of the source target due to the differing deposition rates of the components. The laser ablation method shows the high degree of compliance of the cation stoichiometry of the formed films with the composition of the target material and is characterized by a higher deposition rate compared to other evaporation methods [33]. An important factor is the almost complete absence of film contamination with components of the camera and auxiliary devices' materials due to a small beam width. E-beam PVD, modification of this method, was used for deposition of various electrolyte films [34], [35]. Pulsed laser ablation deposition (PLD) if used for high quality thin films, ease of operation and reproducibility and the films obtained do not require post-treatment at high temperatures.

Sputtering allows a wider range of materials, even with complex stoichiometry, to be deposited. It ensures that the process of obtaining dense films with excellent adhesion and uniformity can be tightly controlled [19], [36]. However, sputtering methods are very expensive and almost all have a very low deposition rate (1 atomic layer/sec).

Among physical methods, plasma spraying, which is now dynamically developing, is worth noting [37]. In this process the sprayed material is fed into a high-temperature plasma jet, heats up, melts and is turned as a two-phase flow to the substrate. Upon impact and deformation, particles interact with the substrate surface or with the sprayed material and form a coating. The method is characterized by high performance and possibility of obtaining coatings of various shapes. When applied to the SOFC technology, this method renders the high-temperature sintering of functional layers unnecessary which greatly simplifies and speeds up the technology. By using low-pressure or high-velocity plasma spraying it is possible to obtain dense electrolyte films [38], [39]. Air plasma spraying (APS) can be successfully used to obtain porous electrodes and protective interconnector layers in an 
integrated technology for producing SOFCs using plasma technology [40]-[42]. However, all these modifications to the plasma spraying method require expensive equipment and are high energy-consuming.

Thus, among the advantages of physical methods one can point out the possibility to produce very thin gas-tight layers on porous substrates and create unique structures that cannot be obtained by other methods. Moreover, highly-dense films can be obtained at a decreased temperature which prevents unwanted interfacial reactions. Among the disadvantages are their high cost and low deposition rate with a few exceptions [43], [44].

\subsection{Chemical methods}

Chemical vapour deposition (CVD) is a chemical process where the final product forms on the target substrate (located in the hottest zone) as a result of the interaction of gaseous precursors or pyrolysis of the precursor vapours. Precursor substances can be not only gases but also solids and liquids; in these cases they are sublimated or evaporated in a special zone of the reactor and then transported to the target substrate by means of a carrier gas. Decomposition of precursors on the substrate surface with the film formation in CVD technology can be carried out by different methods: thermally (TACVD), using plasma (PECVD), ultraviolet radiation (PACVD) or flame (FAVD), etc. If organometallic compounds are used as precursors, this kind of a gas-phase method of deposition of films is designated as MOCVD (metalorganic CVD). The CVD methods vary in pressure during the process (atmospheric pressure, low or very low pressure) and in the physical characteristics of the vapour. The advantages of the method include the possibility of applying films of uniform composition and thickness to substrates with a complex configuration without destroying its structure and, while establishing the process parameters, good reproducibility of the coating properties. The ease of process control and the ability to quickly adjust when changing the substances used is also an advantage of the method. The chemical purity of the product precipitated is quite high. The growth of films, however, is very slow and the cost of equipment is also high [44]. There are examples of the effective use of various modifications of this method for the deposition of SOFC thin films [45]-[47]. However, CVD can be very expensive due to the power requirements of the process. Chemical vapour deposition reactions often leave byproducts which must be removed by a continuous gas flow. Advantages and disadvantages of various CVD methods are comprehensively described in [48].

Electrochemical vapour deposition (EVD) is a modified form of CVD, developed by Westinghouse [49]. At the first stage of the combined CVD/EVD technique the pores of the carrier substrate are closed by simple chemical deposition from the gas phase; at the second stage, the growth of films occurs under the influence of a gradient of electrochemical potential directed across the film. The production of thin-film electrolyte on the supporting anode using this technology has been studied in detail in [46], [50]. In the CVD/EVD process it is possible to determine the electrolyte film quality by performing in situ gas permeation tests [46].

Atomic layer deposition (ALD) is a special kind of chemical vapour deposition, in which a film is formed on a substrate by exposing its surface to alternate gaseous precursors, inserted into the reactor as a series of sequential, non-overlapping pulses. By varying the number of cycles it is possible to grow layers uniformly with precisely controlled thickness and on substrates of complex shapes and of large area [51].

Aerosol spray pyrolysis is a simple and cost effective method compared to other methods of deposition from the gas phase and widely used in SOFC technology to obtain both electrolyte films and electrode layers [52]-[54]. It is based on the thermal decomposition of the 
aerosol of a solution containing cations of the synthesized material in a stoichiometric ratio. When using this method it should be taken into account that, due to different resistance to heat, some salt components can decompose on the way to the substrate and then some of the components will already settle in the form of solid particles and agglomerates, or undergo pyrolysis only after the micro droplet reaches the specified temperature on the substrate. This phenomenon can lead to a decrease in the chemical and phase homogeneity of the films as well as the possible high volatility of some salt components and it is necessary to adjust the composition of the initial solutions, increasing the proportion of volatile components. The negative influence of these factors can be diminished by the introduction of different soluble polymers into working solutions to regulate decomposition temperatures.

\subsection{Chemical solution deposition and colloidal methods}

Chemical solution deposition (CSD) is the method based on deposition of precursors to the substrate from a solution, followed by drying, pyrolysis and high-temperature treatment. As precursors, inorganic salts, hydrides and organometallic compounds soluble in a specific solvent can be used. In some modifications colloidal suspensions or slurries of the powders are used. Liquid precursors can be deposited by spraying, by centrifuging the substrate with a suspension applied on its surface (spin-coating) or immersion of the substrate into the solution followed by its slow withdrawing (dip-coating) [55]-[60]. CSD and related techniques provide versatile and cost-effective processing routes for SOFC thin layers with controlled stoichiometry and morphology on porous substrates. Among the disadvantages of these methods is the necessary numerous repetition of the deposition-drying operation (at temperatures necessary to remove the organic binder, usually $300-400^{\circ} \mathrm{C}$ ) to obtain a dense, porous free coating.

Electrodeposition of SOFC oxide materials can be performed by EPD or electrolytic deposition (ELD). EPD is one of the colloidal processes in which a ceramic film is formed on a substrate from an electrostatically stabilized colloidal suspension in an electric field [22]. ELD produces colloidal particles in electrode reactions for subsequent deposition. As positive qualities of these methods, one can note its simplicity, the uniformity of the films obtained and high deposition rate. For the EPD process preparation of stable suspensions is an important factor for successful deposition [23]. The content of the ceramic component is quite low in comparison to other colloidal methods and usually amounts of 2-10 g/l. ELD are widely used for deposition of protective layers in SOFC as well as deposition of thin electrolyte films and electrodes [63]-[66]. The EPD method is successfully applied to fabricate microtubular SOFCs [65]-[68], fabrication of SOFC electrodes on the supporting dense electrolyte [69], [70] and protective coatings for SOFC interconnects [71], [72]. Electrophoretically deposited electrolyte films exhibit improved adherence and higher density compared with dipped or sprayed coatings and have uniform composition and structure. Gas-tight electrolyte films can be obtained by the EPD method both on conducting cathode and non-conducting anode supports [73], [74].

\section{PROSPECTS FOR USE OF ELECTROLYTE POWDERS OBTAINED BY A LASER EVAPORATION METHOD FOR EPD OF THE THIN-FILM ELECTROLYTES FOR SOFCs}

The EPD method for the fabrication of thin electrolyte films in SOFC technology was chosen by our scientific group for several reasons: it does not require expensive equipment, it is less time-consuming in comparison to the majority of chemical and physical methods (about 
$1 \mu \mathrm{m}$ per minute) and is easily adaptable to changes in the electrolyte compositions and, thus, suitable for deposition of multilayer electrolytes with easy control of the layer thickness through the simple adjustment of the deposition time and applied voltage. It is flexible to the support shape and has no special requirements for binder burnout as the green coatings contain few organics. As far as successful implementation of the EPD process is largely determined by preparation of stable suspensions [75], in this section we share our expertise in preparation of those based on nanopowders, obtained by the method, developed in the Institute of Electrophysics UB RAS [76]-[80]. The use of weak aggregated powders with particles of almost spherical shape obtained by the method of laser evaporation with subsequent condensation (LEC) opens up the potential possibility of obtaining stable self-stabilized suspensions. The use of LEC nanopowders in the EPD technology not only simplifies and significantly reduces the cost of obtaining stable suspensions and the amount of organic dispersants and charge agents but also reduces the sintering temperature and improves the quality of thin-film coatings.

\subsection{Laser evaporation followed by condensation (LEC) as a method of obtaining electrolyte nanopowders}

The production of nanopowders by the LEC method occurs as a result of evaporation of a ceramic target by laser radiation in an evaporation chamber (Fig. 2).

For the evaporation an LS-06 ytterbium fibre laser with $1.07 \mu \mathrm{m}$ wavelength and the average irradiation power output equal to approximately $600 \mathrm{~W}$ is used. The target, made of a purpose material, is installed in the evaporation chamber onto a moving mechanism that provides both rotation and horizontal movement of the target on which the laser beam is focused using an optical system Optoscand d25 f60/200 with $200 \mathrm{~mm}$ focal length. The gas flow blown into the evaporation chamber (a mixture of $\mathrm{N}_{2}$ and $\mathrm{O}_{2}$ in a volume ratio of 0.79 : 0.21 , flow rate of $70 \mathrm{l} / \mathrm{min}$ ) carries away the target vapour formed. In the circulating gas flow, vapour condensation occurs predominantly in the form of spherical nanoparticles, which are then transferred by the working gas flow to a cyclone where the initial separation of the nanoparticles takes place. Next, the flow enters the electric filter on which the final fraction of the weakly aggregated spherical nanoparticles is collected.

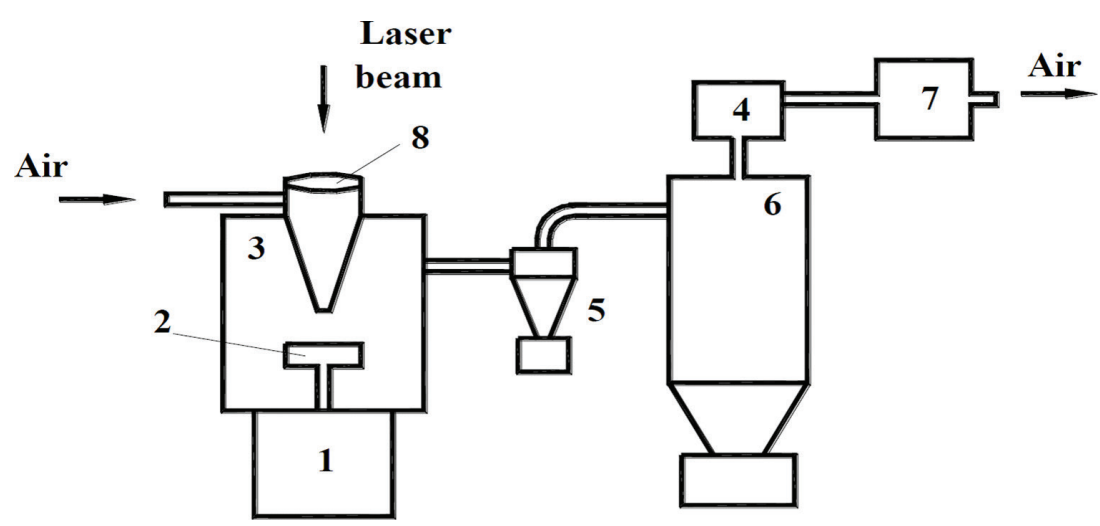

Figure 2: Scheme of the laboratory set for the LEC method (1-moving mechanism, 2-target, 3-evaporation chamber, 4-blower, 5-cyclone, 6-electric filter, 7-mechanical filter, 8-optical system) [76]. 
Examples of LEC nanopowders are shown in Fig. 3. The particles are mainly of spherical shape and the particle size distribution (PSD) obtained by the method of graphical analysis of the TEM images (a JEOL JEM 2100 transmission electron microscope) closely correspond to the lognormal distribution:

$$
f(d)=\frac{1}{d_{P S D} \sigma \sqrt{2 \pi}} e^{-\frac{\left(\ln d_{P S D}-\ln \mu\right)^{2}}{2 \sigma^{2}}}
$$

where $\mu$ is an average value of the logarithm of the particle diameter and $\sigma$ is a dispersion of the normal distribution of the logarithm of the diameter.

The mean diameter of particles $d_{P S D}$ calculated from PSD was in the range of 7-15 nm (Table 1), the specific surface area of the nanopowder, determined by the BET method (a Micromeritics TriStar 3000 vacuum sorption analyzer), exceeded $50 \mathrm{~m}^{2} / \mathrm{g}$. According to the XRD analysis (a D8 DISCOVER diffractometer) all the materials prepared were single phase and exhibited a cubic fluorite-type structure with a $F m 3 m$ (225) space group.
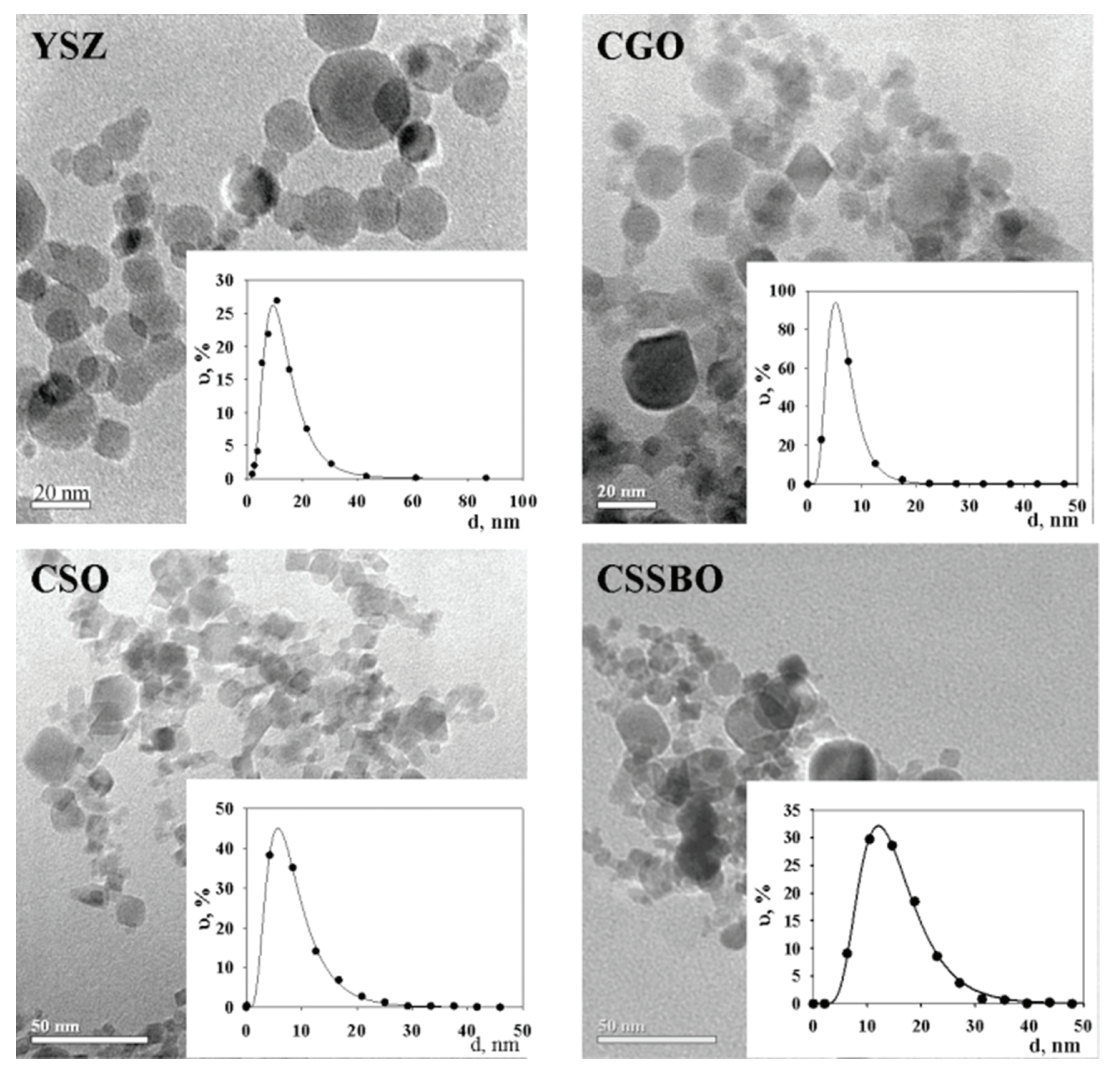

Figure 3: Powder TEM images and particle size distribution in the nanopowders obtained by the LEC method: (a) $\mathrm{Y}_{2} \mathrm{O}_{2}$ stabilized $\mathrm{ZrO}_{2}$ (YSZ); (b) $\mathrm{Ce}_{0.8} \mathrm{Gd}_{0.2} \mathrm{O}_{1.9}$ (CGO); (c) $\mathrm{Ce}_{0.8} \mathrm{Sm}_{0.2} \mathrm{O}_{1.9}$ (CSO); (d) $\mathrm{Ce}_{0.8}\left(\mathrm{Sm}_{0.75} \mathrm{Sr}_{0.2} \mathrm{Ba}_{0.05}\right)_{0.2} \mathrm{O}_{2-\delta}$ (CSSBO) [77], [79], [80]. 
Table 1: XRD characterisation of the LEC nanopowders.

\begin{tabular}{lcccc}
\hline LEC powder & YSZ & CGO & CSO & CSSBO \\
\hline Specific surface area $\left(\mathrm{m}^{2} / \mathrm{g}\right)$ & 55 & 93 & 83 & 53 \\
Mean particle diameter, $d_{P S D}(\mathrm{~nm})$ & 11 & 7 & 9 & 15 \\
Lattice parameter, $a(\mathrm{~nm})$ & 0.5145 & 0.54261 & 0.5429 & 0.5440 \\
\hline
\end{tabular}

\subsection{Effect of self-stabilization in suspensions of the LEC powders}

One of the main conditions for successful EPD is the selection of the dispersion medium which would provide sedimentation and aggregative stability of the suspension. From an economic and environmental point of view the most convenient medium is water. However, the use of water in the EPD processes of ceramic powders is limited, due to the low voltage of water electrolysis which results in gas release during the process preventing the formation of dense coatings [22], [23]. In spite of the fact that there are several studies on successfully conducted EPD in the aqueous medium, such processes, as a rule, require the use of noble metal electrodes [81], [82]. Thus, alcohols and ketones, as well as their mixtures, are usually used as a dispersion medium [83]-[85]. The zeta potential ( $\zeta$-potential) is used as a criterion for the stability of the suspension, that is the potential difference between the liquid medium and the particle interfacial double layer at the slipping plane [23], [75]. A magnitude of $\zeta$-potential above $20 \mathrm{mV}$ is required to maintain a well-dispersed suspension.

For stabilization of non-aqueous suspensions of commercial powders (Tosoh, Nanostructured and Amorphous Materials Inc., Aldrich) different particle charge modifiers and dispersants (iodine) as well as additives of acids or alkalis for $\mathrm{pH}$ and $\zeta$-potential regulation are introduced [74], [83], [86], [87]. The main advantage in using the LEC powders is the spontaneous formation of the electric double layer (EDL) with a positive $\zeta$-potential on the surface of the nanoparticles [88]. The initial suspensions in a mixed isopropanol-acetylaceton medium (50:50) of all nanopowder compositions are characterized by a weak acid medium and a sufficiently high $\zeta$-potential initial value (Fig. 4). During titration with $\mathrm{KOH} \zeta$ potential values decrease with increasing $\mathrm{pH}$ for all the suspensions prepared, however, the charge exchange of EDL does not occur: the $\zeta$-potential values remain positive. To determine the reasons for the absence of an isoelectric point, potentiometric titration was carried out. The shape of the titration curves for various nanopowders was similar: the $\mathrm{pH}$ increases monotonically with $\mathrm{KOH}$ addition and there is no characteristic step indicating the point of equivalence of the acid-base equilibrium. This behaviour is probably a consequence of the non-aqueous nature of the dispersion medium of the suspension, in which the protolytic dissociation constant of the solvent is significantly lower than in water and the point of equivalence can be reached at substantially higher alkali concentrations. The study of suspensions of commercial CGO powder (Fuel cells materials) [89] showed that the isoelectric point in aqueous suspension occurred at neutral $\mathrm{pH}$ value. Such behaviour of the titration curves in our case is probably a consequence of the of the non-aqueous dispersion medium's nature, in which the protolytic dissociation constant of the solvent is significantly lower than in water and the point of equivalence can be reached at substantially higher alkali concentrations. To maintain stability of the water and ethanol-based commercial CGO suspensions, polyacrylamide (Duramax-D3005) in the amount of $3.0 \mathrm{wt} \%$ and phosphate ester (Beycostat-C213) in the amount of $2.0 \mathrm{wt} \%$ were used as deflocculants, respectively [89]. 


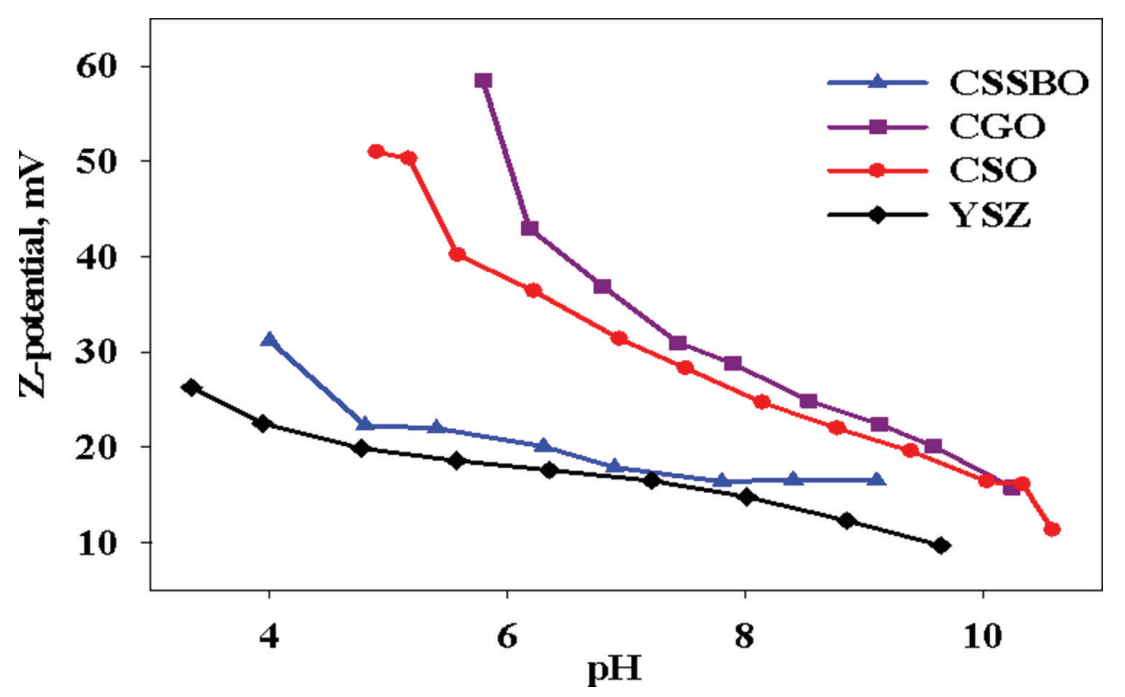

Figure 4: Dependence of $\zeta$-potential on $\mathrm{pH}$ value in the isopropanol/ acetylaceton-based suspensions (50:50) according to the electroacoustic measurements (DT-300 analyzer) [80], [88].

It was shown in our earlier work [90] that nanopowders prepared by electric explosion of wires also formed self-stabilizing suspensions. Moreover, the materials obtained by the wire electrical explosion and LEC methods were similar both in EDL parameters and how they change during the titration $[88,90]$. This gave reason to suppose that they have a similar mechanism to EDL formation based on specific adsorption of cations. However, the nature of the anions in this mechanism is not yet clear. In the case of the powders prepared by explosion it may be a nitrate anion, whereas for the laser powders it may possibly be a condensed form of carbon as small amounts of carbon are always detected in the LEC nanopowders [88]. It should be noted that the stability of these suspensions is primarily caused by the electrostatic factor and the small particle size is of secondary importance. The small particle size in itself does not provide stability of suspensions caused only by thermal motion and even in the presence of electrostatic repulsion between nanoparticles (high $\zeta$-potential values) the suspensions can experience substantial aggregation, which, however, does not always affect its sedimentation stability. In our opinion, the dispersion composition of aggregates in suspension has a significant effect on such characteristics of the resulting coatings as density and the presence of various defects. As a method for producing suspensions with a narrow distribution of particles and their aggregates by size, ultrasonic treatment followed by centrifugation is usually applied. Examples of the application of this technology are given in the next section.

\section{EPD OF THIN ELECTROLYTE FILMS ON DENSE AND POROUS CATHODE SUBSTRATES}

\subsection{Deposition parameters}

Along with such parameters as $\zeta$-potential, viscosity and dielectric constant of the dispersion medium, EPD mode is characterized by such parameters as: voltage between electrodes, 
deposition current, electrode area and deposition time. The kinetics of deposition may vary depending on the properties of the electrokinetic system under consideration. In our works, we experimentally selected EPD modes in non-aqueous media (isopropanol/acetylacetone with different ratios of the components) at constant voltage in the range from 50 to $100 \mathrm{~V}$. Under the conditions used, the deposition time was $1 \mathrm{~min}$ to obtain a green coating thickness of approximately $2 \mu \mathrm{m}$ at a suspension concentration of 10-20 g/l. The polymer modifier BMC-5 (copolymer of butyl methacrylate with $5 \mathrm{wt} \%$ of methacrylic acid) was introduced into the suspensions to avoid cracking the coatings during drying and was limited to a specific value $(3 \mathrm{~g} / \mathrm{l})$, above which the EPD process stops [88].

Below we give some common requirements for the substrates used for EPD, derived from our experimental studies [73], [88], [91], [92]:

- high electrical conductivity and homogeneity of electrical properties along the surface;

- proximity of the thermomechanical properties and sintering behaviour of the substrate and the electrolyte film deposited;

- high level of the substrate porosity (not less than 35 vol\%) to avoid gas diffusion limitations;

- the pore size on the substrate/electrolyte film contact surface not more than $1 \mu \mathrm{m}$;

- surface roughness not more than $0.20 \mu \mathrm{m}$;

- stability of the substrate porous structure during electrolyte sintering.

Because a high level of substrate conductivity is one of the main qualities required for successful deposition of the film by EPD our group conducted deposition on different dense and porous cathode substrates. Deposition on non-conducting substrates (for example, NiOYSZ, deposition on the electrolyte surface) is possible when covering the substrate surface with a conducting material (graphite, polypyrrole) or using a conducting plate (metallic or carbon) placed on the other surface of the substrate which is not exposed to deposition [74], [93], [94].

\subsection{Deposition of YSZ films}

The effect of the degree of de-aggregation of YSZ nanoparticles in suspensions of the LEC powder on the deposition process on the dense $\mathrm{La}_{0.7} \mathrm{Sr}_{0.3} \mathrm{MnO}_{3-\delta}$ (LSM) cathodes was highlighted in [95]. It was shown that the combination of ultrasonic treatment (UST) using a UZV-13/150-TN processor with following centrifugation in a Hermle Labnet Z383 centrifuge lead to a narrow distribution of particle sizes in suspension (Fig. 5). The process of centrifuging the suspension was carried out at different durations-from 1 minute to 9 minutes at the same rotational speed of $10,000 \mathrm{rpm}$. It was established that, when the suspension was processed for 6-9 minutes, the resulting green coating had a porosity of more than $35 \%$, whereas with a treatment time of 3 minutes the green-coating porosity did not exceed $15 \%$ and ensured that dense, crack-free films would be obtained after sintering. From the stable suspensions with varying degrees of de-aggregation, thin-film coatings were obtained using both EPD and model drying on the substrates. It was found that there was a significant difference in the structure and morphology of the films obtained in these two cases: the model drying from the stable suspensions lead to the formation of loose aggregates on the surface; in the case of EPD, electrocoagulation of particles firstly occurred near the cathode with the formation of sufficiently dense aggregates and then the resulting aggregates were deposited on the electrode. 


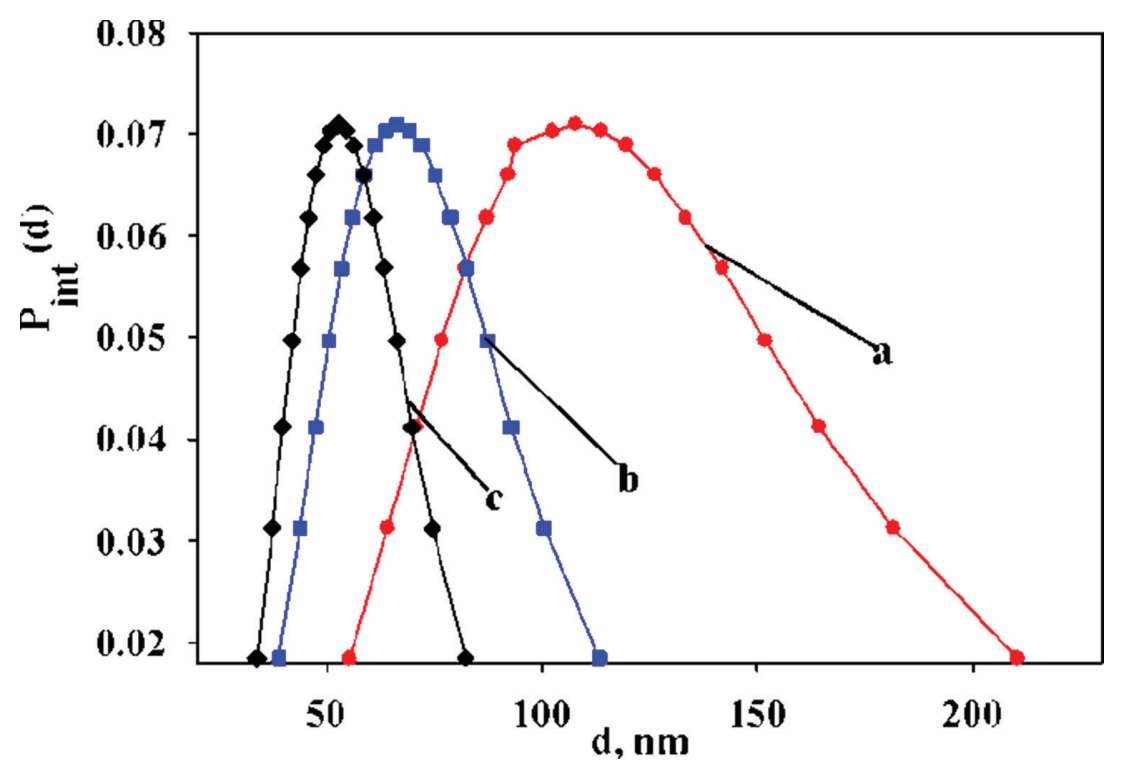

Figure 5: Influence of the YSZ suspension processing on the particle size distribution: (a) UST $125 \mathrm{~min}$; (b) UST $125 \mathrm{~min}+$ centrifugation for $3 \mathrm{~min}$ at 10,000 rpm; (c) UST $125 \mathrm{~min}+$ centrifugation for $6 \mathrm{~min}$ [95].

The EPD from the isopropanol/acetylacetone suspension based on the YSZ powder was also performed on the $\mathrm{La}_{0.6} \mathrm{Sr}_{0.4} \mathrm{MnO}_{3}$ porous substrates with different mean pore sizeLSM1 (up to $1 \mu \mathrm{m}$ ) and LSM2 (3-20 $\mu \mathrm{m}$ ) [92] (Fig. 6a, b). Analysis of the particle size distribution in the suspension before EPD revealed that the percentage of the individual YSZ particles $(14 \mathrm{~nm})$ exceeded that of aggregates $(155 \mathrm{~nm})$ by a factor of 10 . Based on this, the YSZ nanoparticles in both cases should penetrate inside the porous cathode without being deposited on its surface. However, in the case of the LSM1 cathode the YSZ green deposit of high density, consisting of almost spherical formations with a mean size of 100-200 nm, was formed on the surface (Fig. 6c). For the explanation of this fact, it was assumed that on the surface of the electrode an EDL with a finite thickness is also formed. Due to the EDLs of particles and the electrode overlapping, the aggregates were formed and then deposited in the pores near the surface without penetrating into the cathode. Thus, the experimental results have revealed that for the successful deposition from the LEC suspensions the critical pore size on the substrate/electrolyte film contact surface should not exceed $1 \mu \mathrm{m}$.

The possibility of modifying the surface of the LSM2 substrate for further deposition of the nano-sized powder was also validated in [92]. For this, the EPD at $100 \mathrm{~V}$ for $1 \mathrm{~min}$ was carried out to deposit LSM2 electrode material with micron-sized particles in order to close the macropores. The applied intermediate LSM layer $(25 \mu \mathrm{m})$ was annealed at the temperature of $1050^{\circ} \mathrm{C}, 15 \mathrm{~min}$ and then YSZ film $(4 \mu \mathrm{m})$ was electrophoretically deposited onto the modified LSM2 substrate surface (Fig. 6d).

Results of testing the single SOFCs fabricated using EPD are shown in Table 2. Depending on the substrate type, applied EPD mode, film thickness, and fuel/oxidant ratio it varies significantly, from $2.56 \times 10^{-3}$ to $1.84 \mathrm{~W} / \mathrm{cm}^{2}$. The most promising results were obtained in [96], [97] using cyclic EPD both on anode and cathode substrates. For the cell with a 10YSZ 

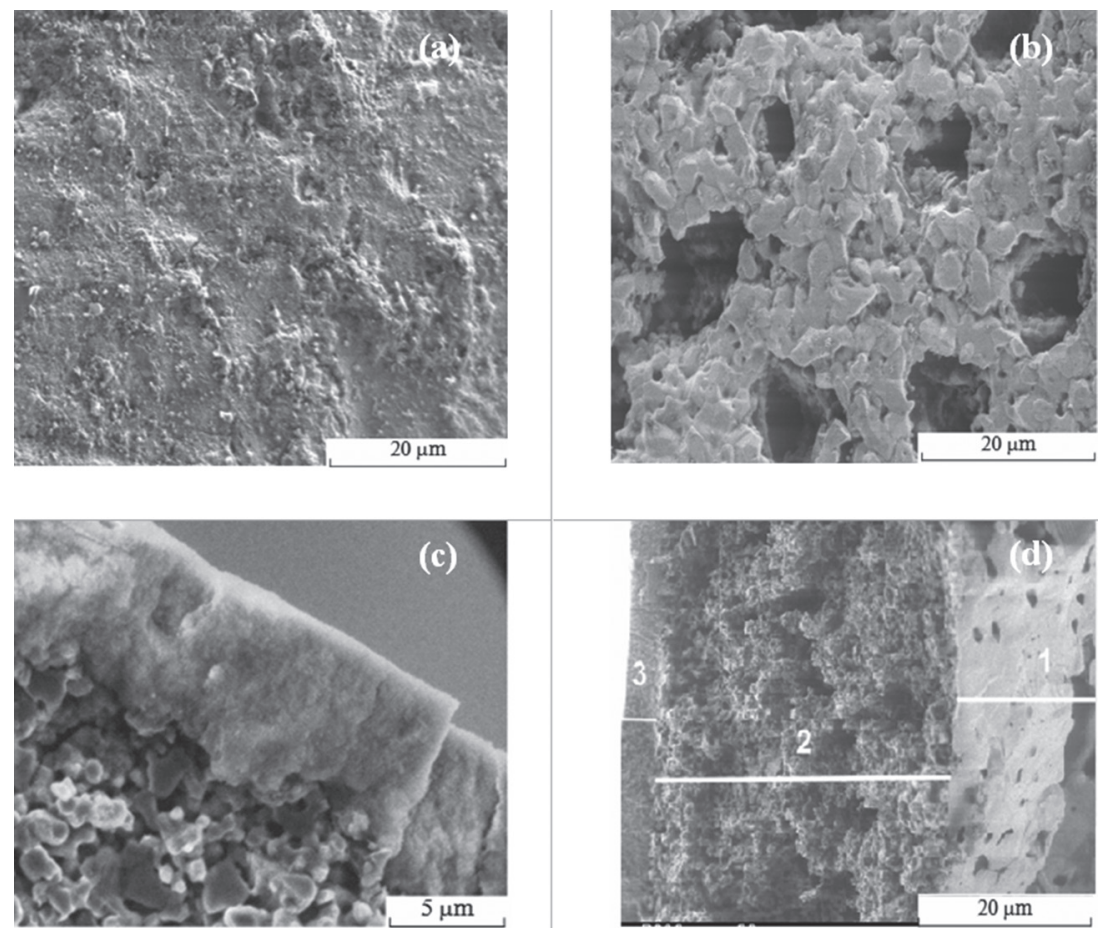

Figure 6: $\mathrm{La}_{0.6} \mathrm{Sr}_{0.4} \mathrm{MnO}_{3}$ porous substrates with different mean pore size: LSM1-up to $1 \mu \mathrm{m}$ (a) and LSM2-3-20 $\mu \mathrm{m}$ (b); YSZ film deposited at LSM1 (c); YSZ film (3) deposited on the intermediate LSM layer (2) at the LSM2 substrate (1) (d) [92].

Table 2: Performance of SOFCs with thin-film YSZ electrolyte fabricated using EPD.

\begin{tabular}{|c|c|c|c|}
\hline $\begin{array}{c}\text { Electrolyte } \\
\text { (thickness, } \mu \mathrm{m})\end{array}$ & $\begin{array}{c}\text { OCV, V } \\
\text { (fuel/oxidant) }\end{array}$ & $\begin{array}{c}P_{\max } \\
W / \mathrm{cm}^{2}\end{array}$ & Ref. \\
\hline *8YSZ $10 \mu \mathrm{m}$ & $\begin{array}{c}\sim 1.0\left(800^{\circ} \mathrm{C}\right) \\
\left(\mathrm{N}_{2}+20 \% \mathrm{H}_{2} / \text { air }\right)\end{array}$ & 0.64 & [67] \\
\hline $8 \mathrm{YSZ}<10 \mu \mathrm{m}$ & $\begin{array}{c}\sim 1.1\left(800^{\circ} \mathrm{C}\right) \\
\left(\mathrm{H}_{2}+3 \% \mathrm{H}_{2} \mathrm{O} / \mathrm{air}\right)\end{array}$ & 0.26 & [68] \\
\hline *8YSZ $40 \mu \mathrm{m}$ & $\begin{array}{c}0.86\left(850^{\circ} \mathrm{C}\right)\left(\mathrm{H}_{2} /\right. \\
\text { air })\end{array}$ & 0.27 & [93] \\
\hline $8 \mathrm{YSZ} 5 \mu \mathrm{m}$ & $\begin{array}{c}1.03\left(1000^{\circ} \mathrm{C}\right) \\
\left(\mathrm{H}_{2}+2 \% \mathrm{H}_{2} \mathrm{O} / \mathrm{O}_{2}\right)\end{array}$ & 1.84 & [96] \\
\hline $8 Y S Z 10 \mu \mathrm{m}$ & $\begin{array}{c}1.0\left(1000^{\circ} \mathrm{C}\right) \\
\left(\mathrm{H}_{2}+3 \% \mathrm{H}_{2} \mathrm{O} / \mathrm{O}_{2}\right)\end{array}$ & 1.5 & [97] \\
\hline$* * 10 \mathrm{YSZ} 5 \mu \mathrm{m}$ & $\begin{array}{c}1.10\left(860^{\circ} \mathrm{C}\right)\left(\mathrm{H}_{2} /\right. \\
\text { air })\end{array}$ & 0.55 & [98] \\
\hline
\end{tabular}




\begin{tabular}{cccc}
\hline $8 Y S Z 9-12 \mu \mathrm{m}$ & $\begin{array}{c}1.08\left(850^{\circ} \mathrm{C}\right)\left(\mathrm{H}_{2} /\right. \\
\text { air })\end{array}$ & 0.57 & {$[99]$} \\
$8 \mathrm{YSZ} 4 \mu \mathrm{m}$ & $\begin{array}{c}1.10\left(700^{\circ} \mathrm{C}\right)\left(\mathrm{H}_{2} /\right. \\
\text { air })\end{array}$ & 0.71 & {$[100]$} \\
$8 \mathrm{YSZ} 4 \mu \mathrm{m} /$ & $\begin{array}{c}1.10\left(700^{\circ} \mathrm{C}\right)\left(\mathrm{H}_{2} /\right. \\
\text { air })\end{array}$ & 0.61 & {$[100]$} \\
$* * * \mathrm{CSO} 201 \mu \mathrm{m}$ & $\begin{array}{c}\sim 1.0\left(800^{\circ} \mathrm{C}\right) \\
\left(\mathrm{N}_{2}+20 \% \mathrm{H}_{2} / \mathrm{air}\right)\end{array}$ & 0.36 & {$[101]$} \\
$8 \mathrm{YSZ} 40 \mu \mathrm{m}$ & $\begin{array}{c}\sim 1.0\left(800^{\circ} \mathrm{C}\right) \\
\left(\mathrm{H}_{2}+3 \% \mathrm{H}_{2} \mathrm{O} / \mathrm{O}_{2}\right)\end{array}$ & $\sim 0.90$ & {$[102]$} \\
$8 \mathrm{YSZ} 3 \mu \mathrm{m}$ & $1.09\left(800^{\circ} \mathrm{C}\right)$ & $2.56 \times 10^{-3}$ & {$[103]$} \\
$8 \mathrm{YSZ} 6.5 \mu \mathrm{m}$ & $\left(\mathrm{H}_{2}+3 \% \mathrm{H}_{2} \mathrm{O} / \mathrm{O}_{2}\right)$ & & \\
\hline
\end{tabular}

*8YSZ $-\mathrm{Zr}_{0.92} \mathrm{Y}_{0.08} \mathrm{O}_{2-\delta} ; * * 10 \mathrm{YSZ}-\mathrm{Zr}_{0.9} \mathrm{Y}_{0.1} \mathrm{O}_{2-\delta} ; * * \mathrm{CSO} 20-\mathrm{Ce}_{0.8} \mathrm{Sm}_{02} \mathrm{O}_{2-\delta}$.

film fabricated on a LSM cathode substrate from a stable suspension of the LEC 10YSZ electrolyte powder the high OCV value $\left(1.10\right.$ at $860^{\circ} \mathrm{C}$ for the fuel/oxidizer mixture of $\left.\mathrm{H}_{2} / \mathrm{Air}\right)$ and performance, comparable with the best results presented in literature were obtained [98].

EPD can also be applied to the deposition of composite and multilayer coatings based on YSZ and other solid state electrolytes [69], [100], [104]-[107]. This method offers the opportunity to deposit very thin layers with high adhesive properties and allows the problem to be resolved with layer delaminating during sintering. For instance, a functionally-graded NiOYSZ composite film was obtained by a controlled voltage-decay EPD process from the suspension containing the particles of two different sizes (fine YSZ and coarse NiO particles) [69]. The film contained varying $\mathrm{NiO}$ concentration from $46 \mathrm{wt} \%$ near the substrate to $32 \mathrm{wt} \%$ close to the electrolyte with $42 \mathrm{wt} \% \mathrm{NiO}$ in the intermediate region. The multilayer structures with 5, 31 and 75 alternating layers of tetragonal 3YSZ (5.22 wt.\% Y2O3) and cubic 8 YSZ zirconia with uniform layers' thickness of 125,55 and $20 \mu \mathrm{m}$ were successfully obtained in [105], [106].

\subsection{Deposition of $\mathrm{CeO}_{2}$-based films}

Some recent studies have been devoted to EPD of $\mathrm{Ce}_{0.8}\left(\mathrm{Sm}_{0.75} \mathrm{Sr}_{0.2} \mathrm{Ba}_{0.05}\right)_{0.2} \mathrm{O}_{2-\delta}(\mathrm{CSSBO})$ electrolyte films both on a dense $\mathrm{La}_{2} \mathrm{NiO}_{4+\delta}(\mathrm{LNO})$ substrate [88], [108] and on a porous substrate consisting of the $\mathrm{LaNi}_{0.6} \mathrm{Fe}_{0.4} \mathrm{O}_{3-\delta}$ (LNFO) collector and $\mathrm{La}_{2} \mathrm{NiO}_{4+\delta}$ functional layers [73].

Suspensions of the CSSBO electrolyte powder (LEC) with concentrations of 10 and $20 \mathrm{~g} / \mathrm{l}$ were ultrasonically treated for 5-125 min. The stable and reproducible results were obtained at $80 \mathrm{~V}$ with the deposition current density equal to $1.5 \mathrm{~A} / \mathrm{cm}^{2}$. Under this regime, deposition of 1 min duration resulted in a uniform CSSBO green deposit of $2.5 \mathrm{mg} / \mathrm{cm}^{2}$ with thickness approximately $2 \mu \mathrm{m}$. The film sintered at $1400^{\circ} \mathrm{C}, 4 \mathrm{~h}$ had a uniform microstructure with an average grain size of $4 \mu \mathrm{m}$ and a total conductivity of $0.1 \mathrm{~S} / \mathrm{cm}$ at $650^{\circ} \mathrm{C}$. It should be noted that, to ensure the operational reliability of the electrolyte layer, especially one based on doped ceria, it is necessary to increase the film thickness to not less than $5 \mu \mathrm{m}$. However, our numerous experimental studies have shown that the maximum thickness of the layer deposited in one stage is about $2-3 \mu \mathrm{m}$. Thus, the cyclic EPD with intermediate sintering at 

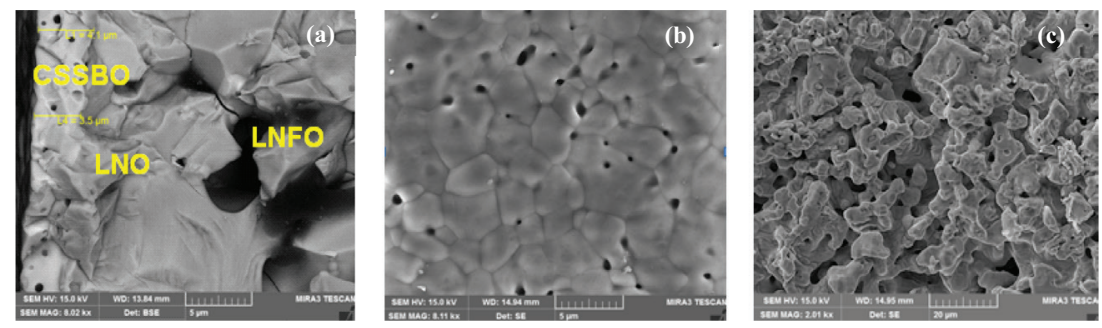

Figure 7: SEM images of the CSSBO film cross-section (a), the film (b) and the LNFO substrate surface structure after the all manufacturing steps of the half-cell, including the final sintering of the electrolyte film at $1400^{\circ} \mathrm{C}, 4 \mathrm{~h}(\mathrm{c})[73]$.

decreased temperatures (6 stages) was performed to deposit the green CSSBO film with a total weight of $5.6 \mathrm{mg} / \mathrm{cm}^{2}$ and $8.5 \mu \mathrm{m}$ thickness on the porous substrate [73]. The film sintered at $1400^{\circ} \mathrm{C}, 4 \mathrm{~h}$ was approximately of $5 \mu \mathrm{m}$ in thickness (Fig. 7) and had surface roughness of about $0.20 \mu \mathrm{m}$. Adhesion to the substrate was studied by the scratching method using a 600 Nanotest device with acoustic emission module. It was shown that the critical load at which the film can be destroyed was $111 \mathrm{mN}$. The amplitude curve of the acoustic emission signal consisted of a single step which confirmed that under the constant increase in load the dissipation of the introduced fracture energy occurred in the form of plastic deformation of the film, excluding the formation of microcracks and destruction occurred at a macroscopic level and under a sufficiently high mechanical load.

The gas permeability coefficient of the electrolyte film measured using a special laboratory device was equal to zero. At the same time, the gas permeability coefficient of the thick supported LNFO layer (1 mm), measured at all stages of the cell manufacturing, was constant and equal to $30.38 \times 10^{-3} \mu \mathrm{m}^{2}$.

\subsection{Deposition of $\mathrm{BaCeO}_{3}$-based films}

Development of proton-conducting electrolytes including those of the $\mathrm{BaCeO}_{3}-\mathrm{BaZrO}_{3}$ series is a promising direction for the SOFCs with decreased operating temperature [109]. Such materials can be used individually or as an electron-blocking component in a composite electrolyte or as a protective layer in the $\mathrm{CeO}_{2}$-based cells [110], [111]. A feature of the $\mathrm{BaCe}(\mathrm{Zr}) \mathrm{O}_{3}$-based electrolytes is their very high sintering temperature which increases with an increase in $\mathrm{Zr}$ content [109]. Because of that the EPD of proton-conducting electrolyte films was previously performed mainly on anode substrates which allows sintering at the temperature of $1500^{\circ} \mathrm{C}$ and higher [112]-[114]. For the EPD on the cathode substrates, due to high sintering properties of majority of cathode materials, to preserve porous structure of the cathode substrate it is necessary to reduce the electrolyte film sintering temperature down to $1400^{\circ} \mathrm{C}$. The LEC method is advantageous in obtaining nano-sized powders for which a decreased sintering temperature is needed to obtain gas-tight coatings. However, in the case of Ba-containing electrolyte, in the LEC process it is difficult to produce powders of nominal compositions, as demonstrated by the specific example of $\mathrm{BaCe}_{0.8} \mathrm{Sm}_{0.2} \mathrm{O}_{3-\delta}$ (BCSO) in [115]. Nevertheless, in the study it was revealed that successive annealing of the BCSO LEC powder at the temperatures of $800-1400^{\circ} \mathrm{C}$ allowed the content of unidentified crystalline phases to be reduced to a trace amount $(<5 \mathrm{wt} \%)$. EPD of the BCSO nanopowder was successfully 
performed using a stable suspension in a mixed isopropanol-acetyl acetone (70/30 vol\%) medium characterized by a high positive $\zeta$-potential of $+30 \mathrm{mV}$ with following final synthesis and sintering in the deposited film at $1400^{\circ} \mathrm{C}$.

Recently, it has been shown that both doping with transition metals and their introduction as a sintering additive allows the sintering temperature of proton conducting electrolyte films to be reduced [116], [117]. On the basis of it, $\mathrm{BaCe}_{0.8} \mathrm{Sm}_{0.19} \mathrm{Cu}_{0.01} \mathrm{O}_{3-\delta}(\mathrm{BCSCuO})$ and $\mathrm{BaCe}_{0.89} \mathrm{Gd}_{0.1} \mathrm{Cu}_{0.01} \mathrm{O}_{3-\delta}(\mathrm{BCGCuO})$ micro-sized powders, obtained by the solid-state reaction and citrate-nitrate combustion methods, were selected for the suspension preparation, characterization and study of the electrokinetic parameters of the EPD process in [118]. Conventional ceramic and chemical methods are more technological from the point of view of providing a single-phase composition of a multi-doped electrolyte material-barium cerates or zirconates substituted with rare-earth elements. It is also expected that suspensions of micro-sized powders are more resistant to aggregation compared to nanopowders [102]. It is known that natural sedimentation stability is not typical for the suspensions of micro-sized powders due to the large aggregate size [23]. The use of ultrasonic processing and centrifugation made it possible to obtain deaggregated stable suspensions of micron particles of BCGCuO and $\mathrm{BCSCuO}$ [118]. The centrifuging process allows the particle size distribution to substantially narrow (Fig. 8), so the effective hydrodynamic diameter and geometric standard deviation for BCGCuO were $294 \mathrm{~nm}$ and 1.376, for a suspension of BCSCuO $329 \mathrm{~nm}$ and 1.472, respectively.

In Ref. [119], to obtain homogeneous, crack-free solid electrolyte films, cyclic EPD was carried out from the $\mathrm{BCSO}$ and $\mathrm{BCGCuO}$ suspensions at a constant voltage of $80 \mathrm{~V}$ and a deposition current in the range from 1.00 to $1.21 \mathrm{~mA} / \mathrm{cm}^{2}$. The deposition time was $1-3 \mathrm{~min}$.

The amount of green deposit in each cycle was $0.4-0.7 \mathrm{mg} / \mathrm{cm}^{2}$ of the geometric surface of the cathode substrate. The total weight of BCGCuO and BCSO films after final sintering was 3.2 and $1.0 \mathrm{mg} / \mathrm{cm}^{2}$, respectively. After the final stage of sintering at a temperature of $1500^{\circ} \mathrm{C}$, the BCGCuO film was dense, with fully formed grains ranging in size from 1 to $7 \mu \mathrm{m}$ with small defects in the form of potholes, which are concentrated on the film surface and are practically absent in its volume. The calculated sintered film thickness (assuming that the particle density is $\mathrm{BCGCuO}=6.35 \mathrm{~g} / \mathrm{cm}^{3}$ ) is $5 \mu \mathrm{m}$, which agrees well with the results of electron microscopy performed using a TESCAN MIRA 3 LMU field emission scanning electron microscope. However, according to the microprobe analysis the spatial distribution of the elements in the BCGCuO film showed a lack of barium which can be caused both by
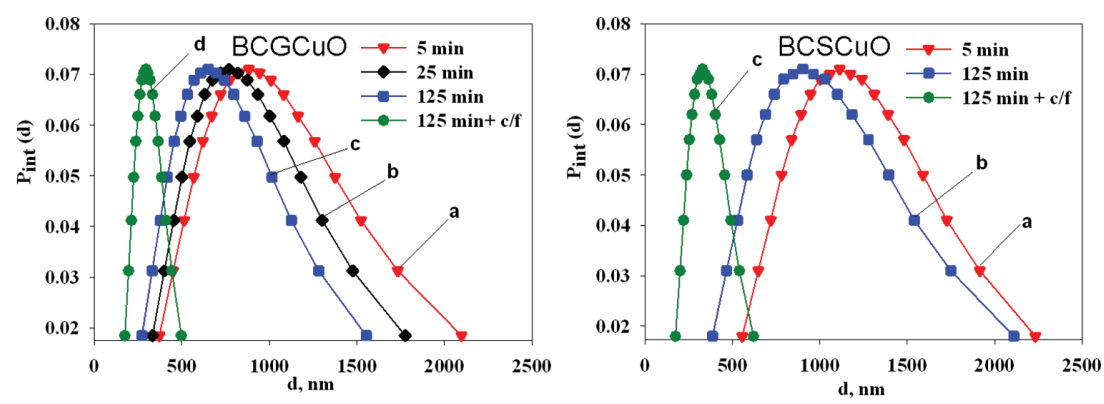

Figure 8: Unimodal distribution for the BCGCuO suspension: (a) UST 5 min; (b) UST $25 \mathrm{~min}$; (c) UST $125 \mathrm{~min}$; (d) Y3O $125 \mathrm{~min}+$ centrifugation $3 \mathrm{~min}$ with the rate of $1500 \mathrm{rpm}$; and for the BCSCuO suspension: (a) UST 5 min; (b) UST $125 \mathrm{~min}$; (c) UST $125 \mathrm{~min}+$ centrifugation $3 \mathrm{~min}$ with the rate of $1500 \mathrm{rpm}$ [118]. 
the more intense evaporation of barium from the film compared to the compact sample and by the diffusion of $\mathrm{Ba}$ into the cathode substrate during sintering. In the literature this problem is considered and possible methods such as covering the film surface with a Ba-containing powder [120] or applying a protective film of undoped $\mathrm{BaCeO}_{3}$ [121] to eliminate the loss of barium during sintering of thin films based on barium cerate are discussed. However, analysis of the chemical composition of the $\mathrm{BCGCuO}$ film both after sintering the film covered with powder of the same material and under the $\mathrm{BaCeO}_{3}$ protective coating (the $\mathrm{BaCeO}_{3}$ layer was electrophoretically deposited on the $\mathrm{BCGCuO}$ film before the final sintering) showed a lack of barium and revealed that the evaporation of barium during sintering is not the determining factor, the main loss of barium being due to diffusion into the LNO substrate. In recent studies [122, 123], Ba-doped layered nickelates have been reported as being most promising for the proton-conducting electrolytes of the $\mathrm{BaCeO}_{3}-\mathrm{BaZrO}_{3}$ series as they show low interaction with the electrolyte along with excellent electrochemical activity and long-term stability. In our recent study, in order to reduce the interaction, the cyclic deposition of the BCGCuO film was performed on the $\mathrm{La}_{1.7} \mathrm{Ba}_{0.3} \mathrm{NiO}_{4}$ (LBNO) model cathodes. The total weight (calculated thickness) of BCGCu coatings sintered at a temperature of $1450^{\circ}$ for 2 hours after 3 and 8 deposition-sintering cycles was $1.2 \mathrm{mg} / \mathrm{cm}^{2}(1.8 \mu \mathrm{m})$ and $2.8 \mathrm{mg} / \mathrm{cm}^{2}(4.4 \mu \mathrm{m})$, respectively. After final sintering almost stoichiometric barium content in the $\mathrm{BCGCuO}$ coating was confirmed. Partial diffusion of lanthanum into the film and no nickel diffusion was detected. The conductivity of the film was $0.107 \mathrm{~S} / \mathrm{cm}$ at $700^{\circ} \mathrm{C}$ with an activation energy of $0.5 \mathrm{eV}$ which is close to the conductivity of a compact sample. Our future work will be directed to the study of EPD of proton-conducting films on the porous cathode substrates.

\section{CONCLUSIONS}

A brief review on the methods for producing thin films in SOFC technology and the research results from our scientific group in the field of EPD of thin-film coatings of solid oxygenconducting and proton-conducting electrolytes based on zirconia, ceria and barium cerate on the cathode substrates have been herein presented. Characteristic features and advantages of EPD compared with other methods for producing coatings have been shown. The EPD method is very attractive for a number of reasons: it does not require expensive equipment, it is flexible to the substrate form, takes less time compared to most chemical and physical methods (about $1 \mu \mathrm{m}$ per minute deposition rate) and is easily adapted to changes in the electrolyte composition and, thus, suitable for deposition of multilayer electrolytes with control of the layer thickness by the time and applied voltage variation. Given that the SOFC electrolyte films can be of various types (oxygen-ion, proton-conducting) and initial powders are of different dispersity (from nano to micro-sized), specific parameters to obtain stable suspensions, prepare the substrate and achieve effective deposition are essential in order to obtain the right recipe for each type of material. Thus, the results of the study of factors influencing the stabilization of suspensions (the influence of the medium, ultrasonic treatment, centrifugation) based on nano- and micro-sized powders (obtained by different methods) and their kinetic parameters have been presented. A number of studies carried out by our scientific group have shown that the combination of ultrasonic processing methods, as well as subsequent centrifugation, allow the proportion of individual particles in the suspension to increase significantly and a narrow particle size distribution to be obtained. The effect of self-stabilization for the suspensions on the basis of weakly aggregated nanopowders $(7-15 \mathrm{~nm})$ with a spherical shape of particles obtained by the method of laser evaporation with subsequent condensation (LEC) was revealed. The LEC suspensions were shown to exhibit high natural positive $\zeta$-potential values of 30-50 mV, suitable for the EPD. The use of LEC powders in the technology of 
preparation of stable suspensions for the EPD was shown to be advantageous since it makes it possible to completely eliminate the use of dispersants and molecular iodine in suspensions. The requirements for electrode substrates were analysed and a model of particle aggregation near the surface of a porous substrate was proposed. Our group carried out the search for cathode materials exhibiting low sintering properties along with high electrochemical activity to satisfy the conditions for the EPD substrate preparation. The results of obtaining dense electrolyte films with a thickness of 2-8 $\mu \mathrm{m}$ using a cyclic EPD on a porous cathode substrate with a carrier (collector) layer of $\mathrm{LaNi}_{0.6} \mathrm{Fe}_{0.4} \mathrm{O}_{3-\delta}$ ( $\mathrm{LNFO}$, of 35-40\% porosity, $1 \mathrm{~mm}$ in thickness) and a thin functional layer of $\mathrm{La}_{2} \mathrm{NiO}_{4+\delta}$ (LNO, $30 \mu \mathrm{m}$, pore size up to $1 \mu \mathrm{m}$ ) with preservation of the substrate porous structure during all the EPD and sintering stages are presented in the review. As was shown, deposition on highly conductive cathode substrates is easier to implement than EPD on non-conductive anode substrates. Deposition on cathode substrates produces high-quality electrolyte films that provide high OCV values and excellent SOFC performance. In this short review, we have endeavoured to increase interest in this simple, low-cost and efficient technology for SOFC production and provide an information base for researchers, especially in Russia, who are starting or continuing their work in this area.

\section{ACKNOWLEDGEMENTS}

This work was performed within the framework of a budget task of the Institute of Electrophysics, UB RAS and the SOFC development task of the Institute of High Temperature Electrochemistry, UB RAS, and partially supported by the Government of the Russian Federation (Agreement 02.A03.21.0006, Act 211). We thank Mr Peter Roy Orman (BA in English Language \& Linguistics VUW, New Zealand) for the manuscript proof-reading.

\section{REFERENCES}

[1] Kendall, K., Portable early market SOFCs. High-temperature Solid Oxide Fuel Cells for the 21st Century (Second Edition). Fundamentals, Design and Applications. ed. K. Kendall \& M. Kendall, Elsevier: Academic Press, pp. 329-356, 2016.

[2] Choudhury, A., Chandra, H. \& Arora, A., Application of solid oxide fuel cell technology for power generation-A review. Renewable and Sustainable Energy Reviews, 20, pp. 430-442, 2013. https://doi.org/10.1016/j.rser.2012.11.031

[3] Zhang, X., Chan, S.H., Li, G., Ho, H.K., Li, J. \& Feng, Zh., A review of integration strategies for solid oxide fuel cells. Journal of Power Sources, 195(3), pp. 685-702, 2010. https://doi.org/10.1016/j.jpowsour.2009.07.045

[4] Silva, F.S. \& Souza, T.M., Novel materials for solid oxide fuel cell technologies: A literature review. International Journal of Hydrogen Energy, 42(41), pp. 26020-26036, 2017. https://doi.org/10.1016/j.ijhydene.2017.08.105

[5] Pikalova, E.Y., Kolchugin, A.A. \& Bamburov, V.G., Ceria-based materials for hightemperature electrochemistry applications. International Journal of Energy Production and Management, 1(3), pp. 272-283, 2016. https://doi.org/10.2495/eq-v1-n3-272-283

[6] Kilner, J.A. \& Burriel, M., Materials for intermediate-temperature solid-oxide fuel cells. Annual Review of Materials Research, 44(1), pp. 365-293, 2014. https://doi. org/10.1146/annurev-matsci-070813-113426

[7] Wachsman, E., Ishihara, T. \& Kilner J., Low-temperature solid-oxide fuel cells. MRS Bulletin, 39(9), pp. 773-779, 2014. https://doi.org/10.1557/mrs.2014.192

[8] Mahato, N., Banerjee, A., Gupta, A., Omar, S. \& Balani, K., Progress in materials selection for solid oxide fuel cell technology: A review. Renewable and Sustainable Energy Reviews, 72, pp. 141-337, 2015. https://doi.org/10.1016/j.pmatsci.2015.01.001 
[9] Will, J., Mitterdorfer, A., Kleinlogel, C., Perednis, D. \& Gauckler, L.J., Fabrication of thin electrolytes for second-generation solid oxide fuel cells. Solid State Ionics, 131(1-2), pp. 79-96, 2000. https://doi.org/10.1016/s0167-2738(00)00624-х

[10] Tuckler, M.C., Progress in metal-supported solid oxide fuel cells: A review. Journal of Power Sources, 195(15), pp. 4570-4582, 2010. https://doi.org/10.1016/j.jpowsour.2010.02.035

[11] Chelmehsara, M.E. \& Mahmoudimehr, J., Techno-economic comparison of anodesupported, cathode-supported, and electrolyte-supported SOFCs. International Journal of Hydrogen Energy, 43(32), pp. 15521-15530, 2018. https://doi.org/10.1016/j. ijhydene.2018.06.114

[12] Nguyen, X.V., Chang, C.T., Jung, G.B., Chan, S.H., Yeh, C.C., Yu, J.W. \& Lee, C.Y., Improvement on the design and fabrication of planar SOFCs with anode-supported cells based on modified button cells. Renewable Energy, 129(B), pp. 806-813, 2018. https://doi.org/10.1016/j.renene.2017.03.070

[13] Mahmud, L.S., Muchtar, A. \& Somalu, M.R., Challenges in fabricating planar solid oxide fuel cells: A review. Renewable and Sustainable Energy Reviews, 72, pp. 105-116, 2017. https://doi.org/10.1016/j.rser.2017.01.019

[14] Huang, K. \& Subhash, C.S., Cathode-supported tubular solid oxide fuel cell technology: A critical review. Journal of Power Sources, 237, pp. 84-97, 2013. https://doi. org/10.1016/j.jpowsour.2013.03.001

[15] Van Gestel, T., Sebold, D. \& Buchkremer, H.P., Processing of 8YSZ and CGO thin film electrolyte layers for intermediate- and low-temperature SOFCs. Journal of the European Ceramic Society, 35(5), pp. 1505-1515, 2015. https://doi.org/10.1016/j.jeurceramsoc.2014.11.017

[16] Noh, H.S., Yoon, K.J., Kim, B.K., Je, H.J., Lee, H.W., Lee, J.H. \& Son, J.W., The potential and challenges of thin-film electrolyte and nanostructured electrode for yttria-stabilized zirconia-base anode-supported solid oxide fuel cells. Journal of Power Sources, 247, pp. 105-111, 2014. https://doi.org/10.1016/j.jpowsour.2013.08.072

[17] Myung, D.H., Hong, J., Yoon, K., Kim, B.K., Lee, H.W., Lee, J.H. \& Son, J.W., The effect of an ultra-thin zirconia blocking layer on the performance of a 1- $\mu$ m-thick gadolinia-doped ceria electrolyte solid-oxide fuel cell. Journal of Power Sources, 206, pp. 91-96, 2012. https://doi.org/10.1016/j.jpowsour.2012.01.117

[18] Shaigan, N., Qu, W., Ivey, D.G. \& Chen, W., A review of recent progress in coatings, surface modifications and alloy developments for solid oxide fuel cell ferritic stainless steel interconnects. Journal of Power Sources, 195(6), pp. 1529-1542, 2010. https:// doi.org/10.1016/j.jpowsour.2009.09.069

[19] Solovyev, A.A., Shipilova, A.V., Ionov, I.V., Kovalchuk, A.N., Rabotkin, S.V. \& Oskirko, V.O., Magnetron- sputtered YSZ and CGO electrolytes for SOFC. Journal of Electronic Materials, 45(8), pp. 3921-3928, 2016. https://doi.org/10.1007/s11664-016-4462-0

[20] Yushina, L.D., Solid Oxide Electrolyte Films, Yekaterinburg: RIO UB RAS, 2012.

[21] Dunyushkina, L.A., Introduction into Fabrication of Thin Electrolyte Films for Solid Oxide Fuel Cells: Monograph, Yekaterinburg: UB RAS, 2015.

[22] Zhitomirsky, I., Cathodic electrodeposition of ceramic and organoceramic materials. Fundamental aspects. Advances in Colloidal and Interface Science, 97(1-9), pp. 279-317, 2002. https://doi.org/10.1016/s0001-8686(01)00068-9

[23] Besra, L. \& Liu, M., A review on fundamentals and applications of electrophoretic deposition (EPD). Progress in Materials Science, 52(1), pp. 1-61, 2007. https://doi. org/10.1016/j.pmatsci.2006.07.001 
[24] Aznami, I., Mah, J.C.W., Muchtar, A., Somlu, M.R. \& Ghazali, M.J., A review of key parameters for effective electrophoretic deposition in the fabrication of solid oxide fuel cells. Journal of Zhejiang University-Science A, 19(11), pp. 811-823, 2018. https://doi. org/10.1631/jzus.a1700604

[25] Hansch, R., Chowdhury M.R.R. \& Menzler, N.H., Screen printing of sol-gel-derived electrolytes for solid oxide fuel cell (SOFC) application. Ceramics International, 35(2), pp. 803-811, 2009. https://doi.org/10.1016/j.ceramint.2008.02.020

[26] Park, S., Gorte, R.J. \& Vohs, J.M., Tape cast solid oxide fuel cells for the direct oxidation of hydrocarbons. Journal of the Electrochemical Society, 148(5), pp. A443-A447, 2001. https://doi.org/10.1149/1.1362538

[27] Jean, J.H., Chang, C.R. \& Chen Z.C., Effect of densification mismatch on camber development during cofiring of nickel-based multilayer ceramic capacitors. Journal of the American Ceramic Society, 80(9), pp. 2401-2406, 2005. https://doi. org/10.1111/j.1151-2916.1997.tb03132.x

[28] Medvedev, D., Lyagaeva, J., Vdovin, G., Beresnev, S., Demin, A. \& Tsiakaras, P., A tape calendering method as an effective way for the preparation of proton ceramic fuel cells with enhanced performance. Electrochemica Acta, 210, pp. 681-688, 2016. https://doi. org/10.1016/j.electacta.2016.05.197

[29] Minh, N.Q., Solid oxide fuel cell technology-features and applications. Solid State Ionics, 174(1-4), pp. 271-277, 2004. https://doi.org/10.1016/j.ssi.2004.07.042

[30] Sun, H., Zhang, Y., Gong, H., Li, Q., By, Y. \& Li, T., Anode-supported SOFCs based on $\mathrm{Sm}_{0.2} \mathrm{Ce}_{0.8} \mathrm{O}_{2-\delta}$ electrolyte thin-films fabricated by co-pressing using microwave combustion synthesized powders. Ceramics International, 42(3), pp. 4285-4289, 2016. https://doi.org/10.1016/j.ceramint.2015.11.105

[31] Dailly, J., Marrony, M., Taillades, G., Taillades-Jacquin, M., Grimaud, A., Mauvy, F. \& Salmi, J., Evaluation of proton conducting BCY10-based anode supported cells by co-pressing method: Up-scaling, performances and durability. Journal of Power Sources, 255, pp. 302-307, 2014. https://doi.org/10.1016/j.jpowsour.2013.12.082

[32] Taillades, G., Pers, P., Mao, V. \& Taillades, M., High performance anode-supported proton ceramic fuel cell elaborated by wet powder spraying. International Journal of Hydrogen Energy, 41(28), pp. 12330-12336, 2016. https://doi.org/10.1016/j. ijhydene.2016.05.094

[33] Garcia-Giron, A., Sola, D. \& Peria, J.I., Liquid-assisted laser ablation of advanced ceramics and glass-ceramic materials. Applied Surface Science, 363, pp. 548-554, 2016. https://doi.org/10.1016/j.apsusc.2015.12.079

[34] Virbukas, D. \& Laukaitis, G., The structural and electrical properties of samarium doped ceria films formed by e-beam deposition technique. Solid State Ionics, 302, pp. 107-112, 2017. https://doi.org/10.1016/j.ssi.2016.12.003

[35] Tanhaei, M. \& Mozammel, M., Yttria-stabilized zirconiz thin film electrolyte deposited by EB-PVD on porous anode support for SOFC applications. Ceramics International, 43(3), pp. 3035-3042, 2017. https://doi.org/10.1016/j.ceramint.2016.11.097

[36] Rezugina, E., Thomann, A.L., Hidalgo, H., Brault, P., Dolique, V. \& Tessier, Y., Ni-YSZ films deposited by reactive magnetron sputtering for SOFC applications. Surface \& Coatings Technology, 204(15), pp. 2376-2380, 2010. https://doi.org/10.1016/j.surfcoat.2010.01.006

[37] Rauch, J., Bolelli, G., Killinger, A, Gadow, R., Cannillo, V. \& Lusvarghi, L., Advances in high velocity suspension flame spraying (HVSFS). Surface \& Coatings Technology, 203(15), pp. 2131-2138, 2009. https://doi.org/10.1016/j.surfcoat.2008.12.002 
[38] Yuan, K., Zhu, J., Dong, W., Yu, Y., Lu, X., Ji, X. \& Wang, X., Applying Low-Pressure Plasma Spray (LPPS) for coatings in low-temperature SOFC. International Journal of Hydrogen Energy, 42(34), pp. 22243-22249, 2017. https://doi.org/10.1016/j. ijhydene.2017.04.215

[39] Berghaus, J.O., Legoux, J.G., Moreau, C., Hui, R., Decès-Petit, C., Qu, W. \& Ghosh, D., Suspension HVOF Spraying of Reduced Temperature Solid Oxide Fuel Cell Electrolytes. Journal of Thermal Spray Technology, 17(5-6), pp. 700-707, 2008. https://doi.org/10.1007/s11666-008-9249-2

[40] Ma, X.Q., Zhang, H., Dai, J., Roth, J., Hui, R., Xiao, T.D. \& Reisner, D.E., Intermediate temperature solid oxide fuel cell based on fully integrated plasma-sprayed components. Journal of Thermal Spray Technology, 14(1), pp. 61-66, 2005. https://doi. org/10.1361/10599630522710

[41] Marcano, D., Mauer, G., Vaßen, R. \& Weber, A., Manufacturing of high performance solid oxide fuel cells (SOFCs) with atmospheric plasma spraying (APS) and plasma spray-physical vapor deposition (PS-PVD). Surface \& Coatings Technology, 318, pp. 170-177, 2017. https://doi.org/10.1016/j.surfcoat.2016.10.088

[42] Puranen, J., Pihlatie, M., Lagerbom, J., Salminen, T., Laakso, J., Hyvärinen, L. \& Vuoristo, P., Influence of powder composition and manufacturing method on electrical and chromium barrier properties of atmospheric plasma sprayed spinel coatings prepared from $\mathrm{MnCo}_{2} \mathrm{O}_{4}$ and $\mathrm{Mn}_{2} \mathrm{CoO}_{4}+\mathrm{Co}$ powders on Crofer 22 APU interconnectors. International Journal of Hydrogen Energy, 39(30), pp. 17246-17257, 2014. https://doi. org/10.1016/j.ijhydene.2014.08.016

[43] Pederson, L.R., Singh, P. \& Zhou, X.D., Application of vacuum deposition methods to solid oxide fuel cells. Vacuum, 80(10), pp. 1066-1083, 2006. https://doi.org/10.1016/j. vacuum.2006.01.072

[44] Itoh, H., Mori, M., Mori, N. \& Abe, T., Production cost estimation of solid oxide fuel-cells. Journal of Power Sources, 49(1-3), pp. 315-332, 1994. https://doi. org/10.1016/0378-7753(93)01831-2

[45] Meng, G., Song, H., Dong, Q. \& Peng, D., Application of novel aerosol-assisted chemical vapor deposition techniques for SOFC thin films. Solid State Ionics, 175(1-4), pp. 29-34, 2004. https://doi.org/10.1016/j.ssi.2004.09.038

[46] Hermawan, E., Lee, G.S., Kim, G.S., Ham, H.C., Han, J.H. \& Yoon S.P., Densification of an YSZ electrolyte layer prepared by chemical/electrochemical vapor deposition for metal-supported solid oxide fuel cells. Ceramics International, 43(13), pp. 10450-10459, 2017. https://doi.org/10.1016/j.ceramint.2017.05.085

[47] Chopade, S.S., Nayak, C., Bhattacharyya, D., Jha, S.N., Tokas, R.B., Sahoo, N.K. \& Rao, G.M., RF plasma enhanced MOCVD of yttria stabilized zirconia thin films using octanedionate precursors and their characterization. Applied Surface Science, 355, pp. 82-92, 2015. https://doi.org/10.1016/j.apsusc.2015.07.090

[48] Choy, K.L., Chemical vapour deposition of coatings. Progress in Materials Science, 48(2), pp. 57-170, 2003. https://doi.org/10.1016/s0079-6425(01)00009-3

[49] Van Dieten, V.E.J. \& Schoonman, J., Thin film techniques for solid oxide fuel cells. Solid State Ionics, 57(1-2), pp. 141-145, 1992. https://doi.org/10.1016/01672738(92)90076-2

[50] Kikuchi, K., Tamazaki, F., Okada, K. \& Mineshige, A., Yttria-stabilized zirconia thin films deposited on $\mathrm{NiO}-\left(\mathrm{Sm}_{2} \mathrm{O}_{3}\right)\left({ }_{0.1}\right)\left(\mathrm{CeO}_{2}\right)\left({ }_{0.8}\right)$ substrates by chemical vapour infiltration. Journal of Power Sources, 162(2), pp. 1053-1059, 2006. https://doi. org/10.1016/j.jpowsour.2006.08.023 
[51] Johnson, R.W., Hultqvist, A. \& Bent, S.F., A brief review of atomic layer deposition: from fundamentals to applications. Materialstoday, 17(5), pp. 236-246, 2014. https:// doi.org/10.1016/j.mattod.2014.04.026

[52] Perednis, D. \& Gauckler L.J., Solid oxide fuel cells with electrolytes prepared via spray pyrolysis. Solid State Ionics, 166(3-4), pp. 229-239, 2004. https://doi.org/10.1016/j. ssi.2003.11.011

[53] Liu, Y., Compson, C. \& Liu, M.L., Nanostructured and functionally graded cathodes for intermediate temperature solid oxide fuel cells. Journal of Power Sources. 138(1-2), pp. 194-198, 2004. https://doi.org/10.1016/j.jpowsour.2004.06.035

[54] Dos Santos-Gómez, L., Hurtado, J., Porras-Vázquez, J.M., Losilla, E.R. \& MarreroLópez, D., Durability and performance of CGO barriers and LSFC cathode deposited by spray-pyrolisis. Journal of the European Ceramic Society, 38(10), pp. 3518-3526, 2018. https://doi.org/10.1016/j.jeurceramsoc.2018.03.024

[55] Engels, J., Griesche, D., Waser, R. \& Schneller, T., Thin film proton conducting membranes for micro-solid oxide fuel cells by chemical solution deposition. Thin Solid Films, 636, pp. 446-457, 2017. https://doi.org/10.1016/j.tsf.2017.06.038

[56] Kuzmin, A.V., Stroeva, A.Y., Plekhanov, M.S., Gorelov, V.P. \& Farlenkov, A.S., Chemical solution deposition and characterization of the $\mathrm{La}_{1-\mathrm{x}} \mathrm{Sr}_{\mathrm{x}} \mathrm{ScO}_{3-\delta}$ thin films on $\mathrm{La}_{1-\mathrm{x}} \mathrm{Sr}_{x} \mathrm{MonO}_{3-\delta}$ substrate. International Journal of Hydrogen Energy, 43(41), pp. 19206-19212, 2018. https://doi.org/10.1016/j.ijhydene.2018.08.114

[57] Morales, M., Navarro, M.E., Capdevila, X.G., Roa, J.J. \& Segarra, M., Processing of graded anode-supported micro-tubular SOFCs based on samaria-doped ceria via gel-casting and spray-coating. Ceramics International, 38(5), 3713-3722, 2012. https:// doi.org/10.1016/j.ceramint.2012.01.015

[58] Antunes, F.C., Goulart, C.A., Andreeta, M.R.B. \& de Souza D.P.F., YSZ/ $/ \mathrm{Al}_{2} \mathrm{O}_{3}$ multilayer thick films deposited by spin coating using ceramic suspensions on $\mathrm{Al}_{2} \mathrm{O}_{3}$ polycrystalline substrate. Materials Science and Engineering: B, 228, pp. 60-66, 2018. https://doi.org/10.1016/j.mseb.2017.11.007

[59] Torabi, A., Etsell, T.H. \& Sarkar, P., Dip coating fabrication process for micro-tubular SOFCs. Solid State Ionics, 192(1), pp. 372-375, 2011. https://doi.org/10.1016/j. ssi.2010.09.050

[60] Hedayat, N., Panthi, D. \& Du, Y., Fabrication of anode-supported microtubular solid oxide fuel cells by sequential dip-coating and reduced sintering steps. Electrochemica Acta, 258, pp. 694-702, 2017. https://doi.org/10.1016/j.electacta.2017.11.115

[61] Jamil, Z., Ruiz-Trejo, E., Boldrin, P. \& Brandon, N.P., Anode fabrication for solid oxide fuel cells: Electroless and electrodeposition of nickel and silver into doped ceria scaffolds. International Journal of Hydrogen Energy, 41(22), pp. 9627-9637, 2016. https://doi.org/10.1016/j.ijhydene.2016.04.061

[62] Ursaki, V.V., Lair, V., Żivković, L., Cassir, M., Ringuedé, A. \& Lupan, O., Optical properties of Sm-doped ceria nanostructured films grown by electrodeposition at low temperature. Optical materials, 34(11), pp. 1897-1901, 2012. https://doi.org/10.1016/j. optmat.2012.05.026

[63] Ananyev, M.V., Solodyankin, A.A., Eremin, V.A., Farlenkov, A.S., Khodimchuk, A.V., Fetisov, A.V. \& Zaikov, Y.P., Protective coatings $\mathrm{La}-\mathrm{Mn}-\mathrm{Cu}-\mathrm{O}$ for stainless-steel interconnector 08X17T for SOFC, obtained by the electrocrystallization method from non-aqueous solutions. Russian Journal of Non-ferrous Metals, 59(1), pp. 102-110, 2018. https://doi.org/10.3103/s1067821218010029 
[64] Park, B.K., Song, R.H., Lee, S.B., Lim, T.H., Park, S.J., Jung, W. \& Lee, J.W., Conformal bi-layered perovskite/spinel coating on a metallic wire network for solid oxide fuel cells via an electrodeposition-based route. Journal of Power Sources, 348, pp. 40-47, 2017. https://doi.org/10.1016/j.jpowsour.2017.02.080

[65] Lawlor, V., Review of the micro-tubular solid oxide fuel cell (Part II: Cell design issues and research activities). Journal of Power Sources, 240, pp. 421-441, 2013. https://doi. org/10.1016/j.jpowsour.2013.03.191

[66] Jamil, S.M., Othman, M.H.D., Rahman, M.A., Jaafar, J., Ismail, A.F. \& Li, K., Recent fabrication techniques for micro-tubular solid oxide fuel cell support: A review. Journal of the European Ceramic Society, 35(1), pp. 1-22, 2015. https://doi.org/10.1016/j.jeurceramsoc.2014.08.034

[67] Yu, F.A., Wu, C.C., Yeh, T.H. \& Cherng J.S., Effects of layer thickness on the performance of micro-tubular solid oxide fuel cells made by sequential aqueous electrophoretic deposition. International Journal of Hydrogen Energy, 40(40), pp. 14072-14076, 2015. https://doi.org/10.1016/j.ijhydene.2015.05.191

[68] Sarkar, P., Yamarte, L., Rho, H. \& Johanson, L., Anode-supported tubular micro-solid oxide fuel cell. International Journal of Applied Ceramic Technology, 4(2), pp. 103-108, 2007. https://doi.org/10.1111/j.1744-7402.2007.02129.x

[69] Zarabian, M., Yar, A.Y., Vafaeenezhad, S., Faghihi Sani, M.A. \& Simchi, A., Electrophoretic deposition of functionally-graded NiO-YSZ composite films. Journal of the European Ceramic Society, 33(10), pp. 1815-1823, 2013. https://doi.org/10.1016/j. jeurceramsoc.2013.01.032

[70] Matsuda, M., Hashimoto, M., Matsunaga, C., Suzuki, T.S., Sakka, Y. \& Uchikoshi, T., Electrophoretic fabrication of a-b plane oriented $\mathrm{La}_{2} \mathrm{NiO}_{4}$ cathode onto electrolyte in strong magnetic field for low-temperature operating solid oxide fuel cell. Journal of the European Ceramic Society, 36(16), pp. 4077-4082, 2016. https://doi.org/10.1016/j. jeurceramsoc.2016.06.043

[71] Mirzaei, M., Simchi, A., Faghihi-Sani, M.A. \& Yazdanyar, A., Electrophoretic deposition and sintering of a nanostructured manganese-cobalt spinel coating for solid oxide fuel cell interconnects. Ceramics Internatonal, 42(6), pp. 6648-6656, 2016. https://doi.org/10.1016/j.ceramint.2016.01.012

[72] Waluyo, N.S., Song, R.H., Lee, S.B., Lim, T.H., Park, S.J. \& Lee, J.W., Electrophoretically deposited $\mathrm{LaNi}_{0.6} \mathrm{Fe}_{0.4} \mathrm{O}_{3}$ perovskite coatings on metallic interconnects for solid oxide fuel cells. Journal of Electrochemical Society, 163(10), pp. F1245-F1250, 2016. https:// doi.org/10.1149/2.1171610jes

[73] Kalinina, E.G., Pikalova, E.Y., Kolchugin, A.A., Pikalov, S.M. \& Kaigorodov, A.S., Cyclic electrophoretic deposition of electrolyte thin-films on the porous cathode substrate utilizing stable suspensions of nanopowders. Solid State Ionics, 302, pp. 126-132, 2017. https://doi.org/10.1016/j.ssi.2017.01.016

[74] Das, D. \& Basu, R., Suspension Chemistry and Electrophoretic Deposition of Zirconia Electrolyte on Conducting and Non-Conducting Substrates. Materials Research Bulletin, 48(9), pp. 3254-3261, 2013. https://doi.org/10.1016/j.materresbull.2013.05.034

[75] Aznam, I., Mah, J.C.W., Muchtar, A., Somalu, M.R. \& Ghazali, M.J., A review of key parameters for effective electrophoretic deposition in the fabrication of solid oxide fuel cells. Journal of Zhejiang University-SCIENCE A (Applied Physics \& Engineering), 19(11), pp. 811-823, 2018. https://doi.org/10.1631/jzus.a1700604 
[76] Kotov, Y.A., Osipov, V.V., Samatov, O.M., Ivanov, M.G., Platonov, V.V., Murzakaev, A.M. \& Timoshenkova, O.R., Properties of powders produced by evaporation $\mathrm{CeO}_{2} /$ $\mathrm{Gd}_{2} \mathrm{O}_{3}$ targets exposed to pulsed-periodic radiation of a $\mathrm{CO}_{2}$ laser. Technical Physics, 49(3), pp. 352-357, 2004. https://doi.org/10.1134/1.1688424

[77] Kotov, Y.A., Osipov, V.V., Ivanov, M.G., Samatov, O.M., Platonov, V.V., Lisenkov, V.V. \& Timoshenkova, O.R., Properties of YSZ and CeGdO nanopowders prepared by target evaporation with a pulse-repetitive $\mathrm{CO}_{2}$-laser. Reviews on Advanced Materials Science, 5, pp. 171-177, 2003.

[78] Ivanov, M., Kotov, Y., Lisenkov, V., Osipov, V., Platonov, V. \& Solomonov, V., Laser synthesis of oxide nanopowders. Advances in Science and Technology, 45, pp. 291-296, 2006. https://doi.org/10.4028/www.scientific.net/ast.45.291

[79] Pikalova, E.Y., Nikonov, A.V., Zhuravlev, V.D., Bamburov, V.G., Samatov, O.M., Lipilin, A.S. \& Molchanova, N.G., Effect of the synthesis technique on the physicochemical properties of $\mathrm{Ce}_{0.8}\left(\mathrm{Sm}_{0.75} \mathrm{Sr}_{0.2} \mathrm{Ba}_{0.05}\right)_{0.2} \mathrm{O}_{2-\delta}$. Inorganic Materials, 47(4), pp. 396-401, 2011. https://doi.org/10.1134/s0020168511040170

[80] Kalinina, E.G., Samatov, O.M. \& Safronov, A.P. Stable suspensions of doped ceria nanopowders for electrophoretic deposition of coatings for solid oxide fuel cells. Inorganic Materials, 52(8), pp. 858-864, 2016. https://doi.org/10.1134/s0020168516080094

[81] Uchikoshi, T., Ozawa, K., Hatton, B.D. \& Sakka, Y., Dense, bubble-free ceramic deposits from aqueous suspensions by electrophoretic deposition. Journal of Materials Research, 16(2), pp. 321-324, 2001. https://doi.org/10.1557/jmr.2001.0048

[82] Cherng, J.S., Sau, J.R. \& Chung, C.C., Aqueous electrophoretic deposition of YSZ electrolyte layers for solid oxide fuel cells. Journal of Solid State Electrochemistry, 12(7-8), pp. 925-933, 2008. https://doi.org/10.1007/s10008-007-0458-2

[83] Chen, F. \& Liu, M., Preparation of yttria-stabilized zirconia (YSZ) films on $\mathrm{La}_{0.85} \mathrm{Sr}_{0.15} \mathrm{MnO}_{3}$ (LSM) and LSM-YSZ substrates using an electrophoretic deposition (EPD) process. Journal of the European Ceramic Society, 21(2), pp. 127-134, 2001. https://doi.org/10.1016/s0955-2219(00)00195-3

[84] Negishi, H., Yamaji, K., Sakai, N., Horita, T., Yanagishita, H. \& Yokokawa, H., Electroforetic deposition of YSZ powders for solid oxide fuel cells. Journal of Materials Science, 39(3), pp. 833-838, 2004. https://doi.org/10.1023/b:jmsc.0000012911.86185.13

[85] Aruna, S.T. \& Rajam, K.S., A study on the electrophoretic deposition of 8YSZ coating using mixture of acetone and ethanol solvents. Materials Chemistry and Physics, 111(1), pp.131-136, 2008. https://doi.org/10.1016/j.matchemphys.2008.03.035

[86] Ichiboshi, H., Myoujin, K., Kodera, N. \& Ogihara, T., Preparation of $\mathrm{Ce}_{0.8} \mathrm{Sm}_{0.2} \mathrm{O}_{1.9}$ Thin Films by Electrophoretic Deposition and their Fuel Cell Performance. Key Engineering Materials, 566, pp. 137-140, 2013. https://doi.org/10.4028/www.scientific.net/kem.566.137

[87] Xu, H., Shapiro, I.P. \& Xiao, P., The influence of $\mathrm{pH}$ on particle packing in YSZ coatings electrophoretically deposited from a non-aqueous suspension. Journal of the European Ceramic Society, 30(5), pp. 1105-1114, 2010. https://doi.org/10.1016/j.jeurceramsoc.2009.07.021

[88] Kalinina, E.G., Pikalova, E.Y., Menshikova, A.V. \& Nikolaenko, I.V., Electrophoretic deposition of a self-stabilizing suspension based on a nanosized multi-component electrolyte powder prepared by the laser evaporation method. Solid State Ionics, $\mathbf{2 8 8}$, pp. 110-114, 2016. https://doi.org/10.1016/j.ssi.2015.12.008 
[89] López-Robledo, M.J., Silva-Treviño, J., Molina, T. \& Moreno, R., Colloidal stability of gadolinium-doped ceria powder in aqueous and non-aqueous media. Journal of the European Ceramic Society, 33(2), 297-303, 2013. https://doi.org/10.1016/j.jeurceramsoc.2012.08.027

[90] Safronov, A.P., Kalinina, E.G., Smirnova, T.A., Leiman, D.V. \& Bagazeev A.V., Selfstabilization of aqueous suspensions of alumina nanoparticles obtained by electrical explosion. Russian Journal of Physical Chemistry A, 84(12), pp. 2122-2127, 2010. https://doi.org/10.1134/s0036024410120204

[91] Kalinina, E.G., Lyutyagina, N.A., Safronov, A.P. \& Buyanova, E.S., Electrophoretic deposition of $\mathrm{Y}_{2} \mathrm{O}_{3}$-stabilized $\mathrm{ZrO}_{2}$ nanoparticles on the surface of dense $\mathrm{La}_{0.7} \mathrm{Sr}_{0.3} \mathrm{MnO}_{3-\delta}$ cathodes produced by pyrolysis and solid-state reaction. Inorganic Materials, 50(2), pp. 184-190, 2014. https://doi.org/10.1134/s0020168514010099

[92] Kalinina, E.G., Safronov, A.P. \& Kotov, Y.A., Formation of thin YSZ electrolyte films by electrophoretic deposition on porous cathodes. Russian Journal of Electrochemistry, 47(6), pp. 671-675, 2011. https://doi.org/10.1134/s1023193511060036

[93] Besra, L., Compson, C. \& Liu, M., Electrophoretic deposition on non-conducting substrates: The case of YSZ film on NiO-YSZ composite substrates for solid oxide fuel cell application. Journal of Power Sources, 173(1), pp.130-136, 2007. https://doi. org/10.1016/j.jpowsour.2007.04.061

[94] Hu, S., Li, W., Yao, M., Li, T. \& Liu, X., Electrophoretic Deposition of Gadolinium-doped Ceria as a Barrier Layer on Yttrium-stabilized Zirconia Electrolyte for SolidOxide Fuel Cells. Fuel Cells, 17(6), pp. 869-874, 2017. https://doi. org/10.1002/fuce.201700122

[95] Kalinina, E.G., Efimov, A.A. \& Safronov, A.P., The influence of nanoparticle aggregation on formation of $\mathrm{ZrO}_{2}$ electrolyte thin films by electrophoretic deposition. Thin Solid Films, 612, pp. 66-71, 2016. https://doi.org/10.1016/j.tsf.2016.05.039

[96] Ishihara, T., Sato, K. \& Takita Y., Electrophoretic deposition of $\mathrm{Y}_{2} \mathrm{O}_{3}$-stabilized $\mathrm{ZrO}_{2}$ electrolyte films in solid oxide fuel cells. Journal of American Ceramic Society, 79(4), pp. 913-919, 1996. https://doi.org/10.1111/j.1151-2916.1996.tb08525.X

[97] Ishihara, T., Shimose, K., Kudo, T., Nishiguchi, H., Akbay, T. \& Takita Y., Preparation of Yttria stabilized zirconia thin films on strontium doped $\mathrm{LaMnO}_{3}$ cathode substrates via electrophoretic deposition for solid oxide fuel cells. Journal of American Ceramic Society, 83(8), pp. 1921-1927, 2004. https://doi.org/10.1111/j.1151-2916.2000. tb01491.x

[98] Ivanov, V.V. et al., Electrophoretic formation of electrolyte layer on cathode surface of cathode supported SOFC. International Journal of Alternative Energy and Ecology (ISJAEE), 10(66), pp. 35-50, 2008.

[99] Horri, B.A., Selomulya, C. \& Wang, H., Electrochemical characteristics and performance of anode-supported SOFCs fabricated using carbon microspheres as a pore-former. International Journal of Hydrogen Energy, 37(24), pp. 19045-19054, 2012. https://doi.org/10.1016/j.ijhydene.2012.10.005

[100] Matsuda, M., Hosomi, T., Murata, K., Fukui, T. \& Miyake, M., Fabrication of bilayered YSZ/SDC electrolyte film by electrophoretic deposition for reduced-temperature operating anode-supported SOFC. Journal of Power Sources, 165(1), pp. 102-107, 2007. https://doi.org/10.1016/j.jpowsour.2006.11.087 
[101] Cherng, J.S., Wu, C.C., Chen, W.H. \& Yeh, T.H., Microstructure and performance of micro-tubular solid oxide fuel cells made by aqueous electrophoretic deposition. Ceramics International, 39, pp. S601-S604, 2013. https://doi.org/10.1016/j.ceramint.2012.10.144

[102] Das, D., Bagchi, B. \& Basu, R.N., Nanostructured zirconia thin film fabricated by electrophoretic deposition technique. Journal of Alloys and Compounds, 693, pp. 1220-1230, 2017. https://doi.org/10.1016/j.jallcom.2016.10.088

[103] Meepho, M., Chuankrerkkul, N., Chauoon, S. \& Pornprasertsuk, R., Process Optimization and Characterization of YSZ Thin Film Electrolyte on Anode Substrate Prepared by Electrophoretic Deposition Technique. Key Engineering Materials, 751, pp. 471-476, 2017. https://doi.org/10.4028/www.scientific.net/kem.751.471

[104] Kalinina, E.G., Efimov, A.A. \& Safronov, A.P., Preparation of YSZ/A12O3 composite coatings via electrophoretic deposition of nanopowders. Inorganic Materials, 52(12), pp. 1301-1306, 2016. https://doi.org/10.1134/s0020168516110054

[105] Mochales, C., Zehbe, R., Frank, S., Rahimi, F., Urbanska, A., Fleck, C. \& Müller, W.D., Multilayered Ceramic Constructs Created by EPD. Key Engineering Materials, 654, pp. 122-126, 2015. https://doi.org/10.4028/www.scientific.net/kem.654.122

[106] Zehbe, R., Mochales, C., Radzik, D., Müller, W.D. \& Fleck, C., Electrophoretic deposition of multilayered (cubic and tetragonal stabilized) zirconia ceramics for adapted crack deflection. Journal of the European Ceramic Society, 36(2), pp. 357-364, 2016. https://doi.org/10.1016/j.jeurceramsoc.2015.08.022

[107] Kalinina, E.G., Pikalova, E.Y. \& Kolchugin, A.A., Formation of Bilayer Thin-Film Electrolyte on Cathode Substrate by Electrophoretic deposition. Russian Journal of Electrochemistry, 54(9), pp. 723-732, 2018. https://doi.org/10.1134/s1023193518090045

[108] Kalinina, E.G., Pikalova, E.Y. \& Scherbinin, S.V., Electrical and mechanical properties of $\mathrm{CeO}_{2}$-based thin-film coatings obtained by electrophoretic deposition. Technical Physics, 63(11), pp. 1636-1641, 2018. https://doi.org/10.1134/s1063784218110130

[109] Medvedev, D., Lyagaeva, J., Plaksin, S., Demin, A. \& Tsiakaras, P., Sulfur and carbon tolerance of $\mathrm{BaCeO}_{3}-\mathrm{BaZrO}_{3}$ proton-conducting materials. Journal of Power Sources, 273, pp. 716-723, 2015. https://doi.org/10.1016/j.jpowsour.2014.09.116

[110] Medvedev, D., Maragou, V., Pikalova, E., Demin, A. \& Tsiakaras, P., Novel composite solid state electrolytes on the base of $\mathrm{BaCeO}_{3}$ and $\mathrm{CeO}_{2}$ for intermediate temperature electrochemical devices. Journal of Power Sources, 221, pp. 217-227, 2013. https:// doi.org/10.1016/j.jpowsour.2012.07.120

[111] Gong, Z., Sun, W., Cao, J., Shan, D., Wu, J. \& Liu, W., $\mathrm{Ce}_{0.8} \mathrm{Sm}_{0.2} \mathrm{O}_{1.9}$ decorated with electron-blocking acceptor-doped $\mathrm{BaCeO}_{3}$ as electrolyte for low-temperature solid oxide fuel cells. Electrochemica Acta, 228, pp. 226-232, 2017. https://doi. org/10.1016/j.electacta.2017.01.065

[112] Bartolomeo, E.D., Zunic, M., Chevallier, L., D’Epifanio, A., Licoccia, S. \& Traversa, E., Fabrication of proton conducting solid oxide fuel cell by using electrophoretic deposition. ECS Transactions, 25(2), pp. 577-584, 2009. https://doi.org/10.1149/1.3205569

[113] Itagaki, Y., Yamamoto, Y., Aono, H. \& Yahiro, H., Anode-supported SOFC with thin film of proton-conducting $\mathrm{BaCe}_{0.8} \mathrm{Y}_{0.2} \mathrm{O}_{3-\delta}$ by electrophoretic deposition. Journal of Ceramic Society of Japan, 125(6), pp. 528-532, 2017. https://doi.org/10.2109/ jcersj2.17048 
[114] Choudhary, B., Anwar, S., Besra, L. \& Anwar, S., Electrophoretic deposition studies of $\mathrm{Ba}(\mathrm{Zr}-\mathrm{Ce}-\mathrm{Y}) \mathrm{O}_{3}$ ceramic coating. Applied Ceramic Technology, 16(3), pp. 1022-1031, 2019. https://doi.org/10.1111/ijac.13152

[115] Kalinina, E.G., Pikalova, E.Y. \& Safronov, A.P., A study of the electrophoretic deposition of thin-film coatings based on barium cerate nanopowder produced by laser evaporation. Russian Journal of Applied Chemistry, 90(5), pp. 701-707, 2017. https:// doi.org/10.1134/s1070427217050056

[116] Ananyev, M., Medvedev, D., Gavrilyuk, A., Mitri, S., Demin, A., Malkov, V. \& Tsiakaras, $\mathrm{P}$., $\mathrm{Cu}$ and $\mathrm{Gd}$ co-doped $\mathrm{BaCeO}_{3}$ proton conductors: Experimental vs SEM image algorithmic-segmentation results. Electrochemica Acta, 125, pp. 371-379, 2014. https://doi.org/10.1016/j.electacta.2013.12.161

[117] Lyagaeva, J., Medvedev, D., Filonova, E., Demin, A. \& Tsiakaras, P., Textured $\mathrm{BaCe}_{0.5} \mathrm{Zr}_{0.3} \mathrm{Ln}_{0.2} \mathrm{O}_{3-\delta}(\mathrm{Ln}=\mathrm{Yb}, \mathrm{Y}, \mathrm{Gd}, \mathrm{Sm}, \mathrm{Nd}$ and $\mathrm{La})$ ceramics obtained by the aid of solid-state reactive sintering method. Scripta Materialia, 109, pp. 34-37, 2015. https://doi.org/10.1016/j.scriptamat.2015.07.012

[118] Kalinina, E.G., Pikalova, E.Y., Zhuravlev, V.D., Scherbinin, S.V. \& Safronov, A.P., Aggregatively stable suspensions of micrometer powders of doped barium cerate for electrophoretic beposition of thin-film coatings of solid-oxide fuel cells. Russian Journal of Applied Chemistry, 90(6), pp. 862-869, 2017. https://doi.org/10.1134/ s1070427217060052

[119] Kalinina, E.G., Pikalova, E.Y. \& Farlenkov, A.S., Electrophoretic deposition of thin-film coatings of solid electrolyte based on microsize $\mathrm{BaCeO}_{3}$ powders. Russian Journal of Applied Chemistry, 91(6), pp. 934-941, 2018. https://doi.org/10.1134/ s1070427218060095

[120] Mercadelli, E., Montaleone, D., Gondolini A., Pinasco, P. \& Sanson, A., Tape-cast asymmetric membranes for hydrogen separation. Ceramics International, 43(11), pp. 8010-8017, 2017. https://doi.org/10.1016/j.ceramint.2017.03.099

[121] Park, I., Kim, J., Lee, H. \& Shin, D., $\mathrm{BaCeO}_{3}-\mathrm{BaCe}_{0.8} \mathrm{Sm}_{0.2} \mathrm{O}_{3-\delta}$ bi-layer electrolytebased protonic ceramic fuel cell. Solid State Ionics, 252, pp. 152-156, 2013. https:// doi.org/10.1016/j.ssi.2013.05.010

[122] Pikalova, E.Y. \& Kolchugin, A.A., The influence of the substituting element $(\mathrm{M}=\mathrm{Ca}$, $\mathrm{Sr}, \mathrm{Ba})$ in $\mathrm{La}_{1.7} \mathrm{M}_{0.3} \mathrm{NiO}_{4}+\delta$ on the electrochemical performance of the composite electrodes. Eurasian Chemico-Technological Journal, 18(1), pp. 3-11, 2016. https:// doi.org/10.18321/ectj386

[123] Danilov, N., Lyagaeva, J., Vdovon, G., Pikalova, E. \& Medvedev, D., Electricity/ hydrogen conversion by the means of a protonic ceramic electrolysis cell with $\mathrm{Nd}_{2} \mathrm{NiO}_{4+\delta}$-based oxygen electrode. Energy Conversion and Management, 172, pp. 129-137, 2018. https://doi.org/10.1016/j.enconman.2018.07.014 